ac.

PEN ACCESS

EDITORS

- Miguel Oliveira, Jr. (UFAL)

- René Almeida (UFS)

REVIEWERS

- Marina Vigário (ULisboa)

- Carmen Matzenauer (ULisboa)

DATES

- Received: 11/30/2020

- Accepted: 23/03/2021

- Published: 06/07/2021

HOW TO CITE

SANTOS, Raquel Santana (2021). The Acquisition of External Vowel Sandhi In Brazilian Portuguese. Cadernos de Linguística, v. 2, n. 1, e340
RESEARCH REPORT

\section{THE ACQUISITION OF EXTERNAL VOWEL SANDHI IN BRAZILIAN PORTUGUESE}

\author{
Raquel Santana SANTOS \\ Faculdade de Filosofia, Letras e Ciências Humanas - Departamento de \\ Linguística - Universidade de São Paulo (USP)
}

\section{ABSTRACT}

In this paper I discuss the acquisition of three external vowel sandhi rules (elision, diphthongization, and degemination) in Brazilian Portuguese, based on production data by two children from 1;4 to 3;6 years old. I argue that the acquisition of sandhi rules is dependent on the acquisition of syllable structure. Children are shown to incorrectly apply elision over diphthongization when they start applying sandhi rules, because they do not master the syllable structures that allow them to produce diphthongs. I also show that the properties of the rules are not mastered simultaneously and that the properties related to higher prosodic domains are the first ones to be acquired.

RESUMO

Neste artigo, discuto a aquisição de três regras de sândi vocálico externo (elisão, ditongação e degeminação) em Português Brasileiro, tomando como base a produção de duas crianças entre 1;4 e 3;6 anos. Argumento que a aquisição das regras de sândi é dependente da aquisição da estrutura silábica. As crianças aplicam incorretamente a elisão no lugar da ditongação quando começam a aplicar as regras de sândi porque elas ainda não dominam as estruturas silábicas que lhes permitem produzir ditongos. Mostro também que as propriedades das regras não são dominadas ao mesmo tempo e que a propriedades relacionadas com os domínios prosódicos mais altos são as primeiras a serem adquiridas. 


\section{KEYWORDS}

Language Acquisition; Brazilian Portuguese; External Vowel Sandhi.

PALAVRAS-CHAVE

Aquisição da Linguagem; Português Brasileiro; Sândi Vocálico Externo. 


\section{INTRODUCTION}

Although the acquisition of phonology has received much attention since the earliest studies on language acquisition, the focus has been almost entirely on phonological processes that occur in child language and not on the acquisition of the rules that describe phonological processes in adult language. In fact, the literature on the acquisition of adult rules is considerably scarce (see, for instance, Klein, 1984; Dresher; Kaye, 1990; Fikkert, 1994 on the acquisition of primary stress). In particular, little is known about the acquisition of betweenword processes that occur in adult language (see Drachman, 1973 on the assimilation of place of articulation between clitics and nouns; Demuth, 1993 on tonal alternations in Sesotho; Bernhardt; Stemberger, 1998 on between-word palatalization and tapping in English; and Newton; Wells 1999, 2002 on juncture processes). This paper makes a contribution to broadening the understanding of how children acquire adult rules by investigating the acquisition of three sandhi rules in Brazilian Portuguese: elision, diphthongization, and degemination.

There are two different views on how children acquire adult rules. The first approach is represented by Stemberger (1989), who analyzed speech errors in adults' and children's utterances both within and between words, and Newton and Wells $(1999,2002)$, who studied children's production of assimilation, elision, and liaison between words. Stemberger (1989) claims that "adult language production mechanisms are largely in place and operating normally from a very early beginning". In other words, for him "there seem to be no points of discontinuity or radical reorganization in the development" (STEMBERGER, 1989, p. 86). This view later leads Bernhardt and Stemberger (1998) to "speculate that alternations involving deletion of an element should be acquired early and possibly without error" (Bernhardt; Stemberger, 1998, p. 637). In the same vein, Newton and Wells (2002) propose that the application of juncture processes is automatic; what must be learned - and this is the difference between adults' and children's outputs - is the articulation of individual gestures and intergestural overlaps. According to them, assimilation and elision appear as early as the production of two-word utterances. They acknowledge that there is a pattern of development in the realization of assimilation and elision, but attribute this pattern to imprecise gestural articulations, which need to be mastered by the child.

The second approach to the acquisition of adult rules is explored by Scarpa (1997), Abaurre, Galves and Scarpa (1999), and Komatsu and Santos (2007), among others, who argue that the rules of diphthongization, elision, and degemination are indeed acquired and that children make errors in this developmental process. Komatsu and Santos (2007), for instance, show that children's production of elision, diphthongization, and degemination changes throughout the acquisition process and that three distinct stages can be identified. 
This paper provides further evidence for the second approach to the acquisition of phonological rules mentioned above. Based on an expansion of the corpus examined by Komatsu and Santos (2007) and Santos (2007, 2009), I investigate the acquisition of external sandhi rules in Brazilian Portuguese (henceforth BP) and its interaction with the acquisition of syllable structure and prosodic prominences. I argue that the properties of degemination, elision, and diphthongization in BP are not mastered simultaneously and that the properties related to higher prosodic domains are the first ones to be acquired. As an alternative to Newton and Wells's (2002) proposal that children overapply elision because this rule is automatic, I show that this overapplication is related to the acquisition of syllable structure.

The paper is organized as follows. Section 2 describes the application of these three rules in adult BP, in the dialect the children are exposed to. Section 3 presents previous studies on language acquisition in BP that are relevant to the present discussion. Section 4 lists the hypotheses that will be entertained here. Section 5 describes the methodology of this study. Section 6 describes the use of sandhi rules by the children under investigation. Section 7 discusses the results in face of the hypotheses raised in section 3. Finally, section 8 presents some concluding remarks.

\section{EXTERNAL VOWEL SANDHI IN BRAZILIAN PORTUGUESE: ADULT LANGUAGE}

Before we consider the specific properties of vowel degemination, elision, and diphthongization in BP, it should be pointed out that they have two common features, besides involving two adjacent vowels from two different words. First, none of these rules is sensitive to morphological information. The last vowel of the nouns and verbs in (1) in BP, for instance, may be subject to deletion (either by degemination or elision) or diphthongization, despite corresponding to different independent morphemes:

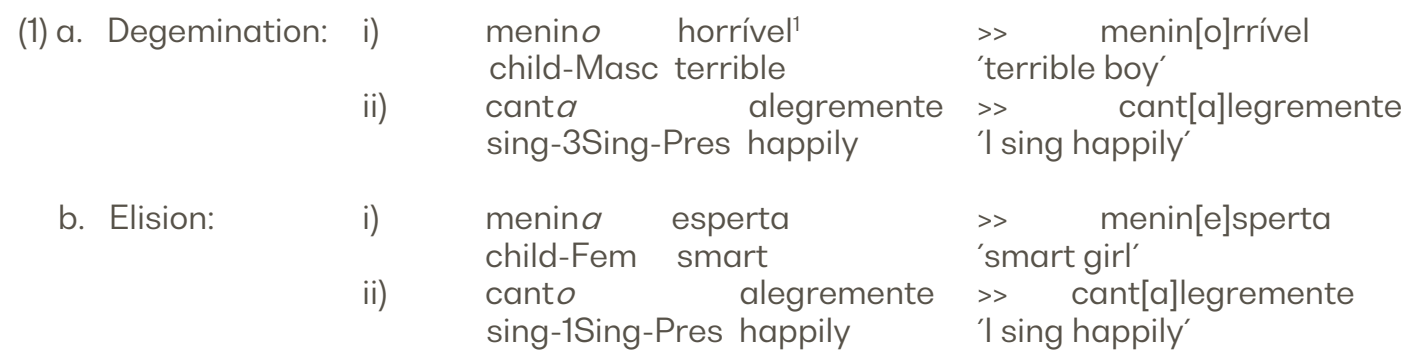




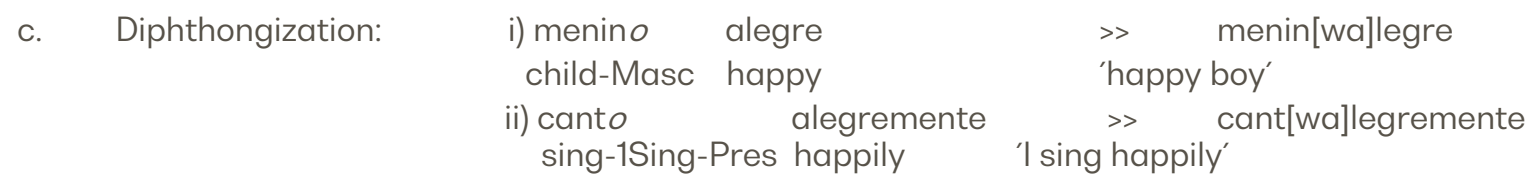

Secondly, sandhi rules in BP are only obligatory inside phonological phrases; in other domains, they are optional (see Tenani 2002). ${ }^{2}$ This is illustrated by the contrast between (2) arid (3): 3

$\begin{array}{clllllll}\text { (2) a. [eu vi } & {[0} & \text { meNlno]ø]। } & {[e} & \text { ele fingiu }] & \text { não me VER]। } \\ \text { l saw the boy } & \text { and he pretended not me see }\end{array}$ 'I saw the boy and he pretended he didn't see me.'

b. Diphthongization: eu vi o [mi.'ni.nwi.'e.li] fingiu não me ver.

c. Elision: eu vi o [mi.'ni.ni.'e.li] fingiu não me ver.

d. No application: eu vi o [mi.'ni.nu.i.'e.li] fingiu não me ver.
(3) a. [ eu $\quad$ Vi $\quad$ [o $\quad$ meNlno esPERto ]ø ] I Saw the boy smart

'I saw the smart boy.'

b. Diphthongization: eu vi o [ mi.'ni.nwis.'per.tu]

c. Elision: eu vi o [mi.'ni.nis.'per.tu]

d. No application: $\quad$ * eu vi o [ mi.'ni.nu.is.'per.tu]

The context for sandhi application in (2a) involves two intonational phrases and we may find either diphthongization (cf. (2b)) or elision (cf. (2c)). It may also be the case that no process applies, as seen in (2d). By contrast, the relevant context in (3a) is inside a phonological phrase and either diphthongization (cf. (3b)) or elision (cf. (3c)) must apply; lack of application of one of these rules is not an option (cf. (3d)).

Below the distinct segmental and prominence properties of each rule in BP are discussed separately.

\subsection{VOWEL DEGEMINATION}

Vowel degemination applies between two adjacent vowels of different syllables with the same segmental characteristics, resulting in a CV syllable. According to Bisol (1996), vowel degemination in BP involves fusion between the two vowels, which can be followed by a shortening of the fused segment. There is no restriction on the segmental properties of the vowels. Both full and reduced vowels can undergo degemination, as seen in (4):4

2 On the construction of prosodic domains, see Nespor and Vogel (1986).

3 Syllables relevant for the application of sandhi rules are in italics; syllables with word stress are in capital letters; and syllables with intonational prominence are underlined. Only the relevant prosodic domains are marked in the examples.

4 Final post-tonic /e/ and /o/ are often reduced to [I] and [ $ซ$ ] in BP 
(4) a. filme ecônomico: film[I][e]conômico or film[e][e]conômico >> film[e]conômico movie inexpensive 'inexpensive movie'

b. quadro horrível: quadr[v] [o]rrível or quadr[o] [o]rrível $\gg$ quadr[o]rrível painting horrible 'horrible painting'

As for the prominences of the syllables involved, the rule may apply between two weak syllables (cf. (5)), a strong and a weak syllable (cf. (6)), or a weak and strong syllable (cf. (7)), but not between two strong syllables (cf. (8)) or if one syllable carries intonational prominence (cf. (9) and (10)): 5

(5) [ eu comprei [um QUAdro

hoRRivel ]ø ]।

>>

['kwa.dso.'xi.vew]

I buy-past a painting

horrible

'I bought a horrible painting'

(6) [ ele [ fala $R A \quad a m a N H A ̃] \varnothing]$

> [fa.la.'`ca.mã.'nã]

he speak-fut tomorrow

'He will speak tomorrow.'

(7) [ela é [uma meNIna]ø

[ALta deMAIS] $]]_{1} \quad$ > $\quad$ [me.'ni.'naw.ta.de.'majs]

she is a girl tall too

'She is a very tall girl.'

(8) [ele fala $R A$ ] $\varnothing$

[ALto deMAIS ]ø ],

he speak-fut

loud too

'He will talk too loud.'

(9) [ ele [SAbe

Isso ]ø]।

> $\quad$ ['sa.'bi.su]

he knows

this

'He knows this.'

(10) [[a meNlna fala $R \dot{A}] \varnothing]_{1}[[a \mathrm{MÃE}$ ficaRÁ quiEta $] \varnothing]$ the girl talk-fut the mother stay-fut quiet

'The girl will talk, the mother will stay quiet.'

\subsection{ELISION}

Elision in BP deletes the first vowel, ${ }^{6}$ which according to Bisol (2003) must be a weak /a/ followed by a vowel other than /a/, as in (11). In fact, the rule must be less restricted, at least for the dialect we are discussing here (the paulista dialect). ${ }^{7}$ In this dialect, elision may also

\footnotetext{
5 The column on the left indicates the prosodic domain, and the one on the right shows the phonetic transcription of the example.

6 See Casali 1997 for the other possibility in different languages.

7 Bisol (1996) actually suggests that although it is possible to apply elision with other vowels, the rule is not general. However, she does not elaborate on this suggestion.
} 
apply when the first vowel is [+high] and [+back] (/o/) - cf. (12). So, I assume here that at least for the dialect under consideration, the elision rule requires that the first vowel be a weak [+back] vowel and that the second vowel be different from the first one. ${ }^{8}$

$\begin{array}{ccrr}\begin{array}{c}\text { (11) casa } \\ \text { house }\end{array} & \begin{array}{l}\text { eNORme } \\ \text { Huge }\end{array} & \gg & \text { ['ka.ze. 'nor.mI] } \\ \text { (12) gaROto } & \text { 'huge house' } \\ \text { boy } & \text { eleGANte } & \gg & \\ \text { [ga.'ro.te.le.'gãtf] }\end{array}$

As for the prominences involved, Bisol (2003) and Abaurre, Galves, and Scarpa (1999) show that elision applies if both syllables are unstressed (cf. (11) and (12)) or if the first syllable is weak and the second vowel carries word stress - provided that it is not the main stress of its phonological phrase (cf. (13)). Thus, elision is blocked whenever the first syllable carries word stress (cf. (14) and (15)) or the second syllable carries phonological phrase stress (cf. (16) vs. (13)):

(13) [ eu [masTIgo]ø I chew-1sg-PRES

(14) [ele [compraRÁ he buy-3sg-FUT

(15) [ele [compra RÁ]ø he buy-3sg-FUT

(16) [eu [masTIgo I chew-1sg-PRES

\begin{tabular}{|c|c|c|c|}
\hline \multirow{3}{*}{\multicolumn{2}{|c|}{$\begin{array}{l}{[\text { ERvas aMARgas] } \varnothing] \mid>} \\
\text { herbs bitter } \\
\text { omeLEtes] }]_{।} \\
\text { Omelets }\end{array}$}} & & \multirow{5}{*}{ 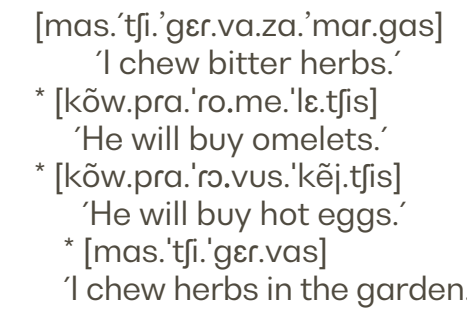 } \\
\hline & & & \\
\hline & & & \\
\hline & & & \\
\hline & & & \\
\hline
\end{tabular}

\subsection{DIPHTHONGIZATION}

Diphthongization applies in the context of two vowels, provided that one of them is [+high], and is the only sandhi rule that does not result in a CV syllable. According to Lopes (1979), Bisol (1999), and Mateus and D'Andrade (2000), in rising diphthongs (which result from a $V_{[+h i g h]}+\mathrm{V}$ sequence), the glide $(G)$ fills the onset position in both European and Brazilian Portuguese. Their main arguments in favor of this proposal involve the interaction of diphthongization with other phonological rules. For instance, nasalization in Portuguese spreads to the segments in the rhyme; if the glide of rising diphthongs were in the rhyme, it should be nasalized, but this does not happen. As for falling diphthongs (which result from a $\mathrm{V}+\mathrm{V}_{\text {[thigh] }}$ sequence), the glide is taken to fill the nucleus position, again in both European and Brazilian Portuguese. This

8 I will put aside apparent cases of elision such as (i) - in which the first vowel is [+front] -, which Nogueira (2007) argues result from a phonetic deletion process triggered by the [coronal] feature of the preceding consonant: 
accounts, for instance, for the fact that / $\mathrm{x}$ / occurs after a CVC syllable, but not after a CVG syllable (see CÂMARA JR, 1970, and MATEUS; D'ANDRADE, 2000).

As far as the relevant prominences are concerned, Bisol (2003) shows that diphthongization in BP may apply between two weak syllables (cf. (17)), a strong and a weak syllable (cf. (18)), a weak and a strong syllable (cf. (19)), or two strong syllables (cf. (20)). However, it is blocked if the second syllable carries intonational stress, as shown in (21) (with a weak and a strong syllable) and in (22) (with two strong syllables):

\begin{tabular}{|c|c|c|c|}
\hline $\begin{array}{l}\text { (17) [eu vi [ o maCAco } \\
\text { I see-1sg-PAST the monkey }\end{array}$ & $\begin{array}{l}\text { ofricAno ]ø]l } \\
\text { African }\end{array}$ & $\gg$ & $\begin{array}{l}\text { [ ma.'ka.kwa.fri.'kã.nu ]ø } \\
\text { 'I saw the African monkey. }\end{array}$ \\
\hline (18) [eu comi & umide $\underline{\text { lddo] }] ~] l ~}$ & $>>$ & [ka. 'zaw.mi.de.'si.du]ø \\
\hline I eat-1sg-PAST hog-plum & wetted & & 'I ate a wetted hog-plum.' \\
\hline (19)[ [o moLEque & Árabe ]ø salU]]ø ]l & $>>$ & [o.mu.'le.'kja.ra.bi.sa.'iw]l \\
\hline the boy & Arab leave-3sg-PAST & & 'The Arab boy left.' \\
\hline (20) [eu [coMI & Was EREScas ]ø ]I & $>$ & [ew.ko.'mju.vas.'fres.kas]l \\
\hline I eat-1sg-PAST & grapes fresh & & 'I ate fresh grapes.' \\
\hline [o moLEque & Árabe]ø ]l & $>$ & *[mu.'Ic.'kja.ra.bi] \\
\hline I see-1sg-PAST the boy & Arab & & 'I saw the Arab boy' \\
\hline (22) [eu [coMI & Uvas ]ø]l & $>>$ & *[ew.ko.'mju.vas] \\
\hline I eat-1sg-PAST & grapes & & 'I ate grapes.' \\
\hline
\end{tabular}

\subsection{SUMMARY}

Table 1 summarizes the properties of the three rules discussed above: ${ }^{9}$

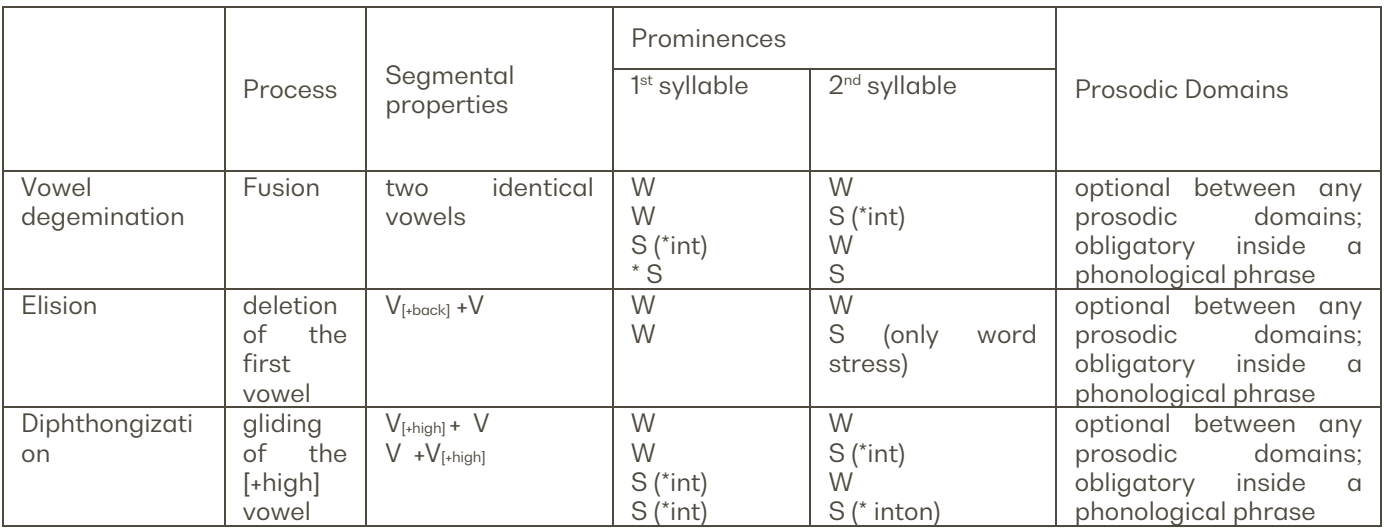

Table 1. Summary of external vowel sandhi rules in Brazilian Portuguese.

9 The asterisks indicate impossibility. Therefore, ${ }^{*} i n t$ indicates that the stressed syllable cannot bear intonational prominence and ${ }^{*} S S$ indicates that the sequence of two strong syllables blocks the application of the rule. 
As can be seen in Table 1, there are contexts where either diphthongization or elision can apply. ${ }^{10}$ The relevant context in (23a) below, for instance, involves two weak syllables, one of them is [+back] - fulfilling the requirement for elision, yielding (23b) - and the other one is [+high] - fulfilling the requirement for diphthongization, yielding (23c). In cases like this, adults employ either option.

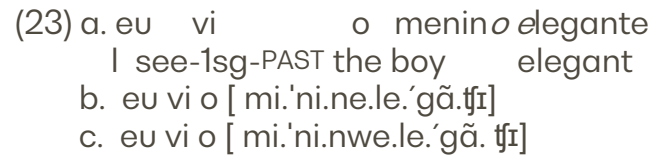

'I saw the elegant boy.'

\subsection{DISTRIBUTION OF THE RULES IN ADULT LANGUAGE}

As mentioned above, the three rules discussed here are optional in BP (when they are not inside phonological phrases). Based on an experiment on sandhi rules, Nogueira (2007) reports that when the relevant context is satisfied, adult speakers of the paulista dialect studied here apply diphthongization in $65 \%$; degemination in $100 \%$, and elision in $43 \%$ of the cases; when the context allows for either elision or diphthongization, adults prefer elision (82.6\%) over diphthongization (16.6\%).11

In order to check if the production of sandhi by the children studied here was affected by the distribution of sandhi processes in adult speech, I computed the application of sandhi rules in their mothers' utterances, in two sessions. There were 459 contexts for external vowel sandhi which were organized according to the applicable processes (elision, diphthongization, degemination, and elision and diphthongization - when both processes were possible) and the outputs (no application, diphthongization, elision, degemination). As can be seen in Table 2 below, the main differences are on the use of elision. ${ }^{12}$ When only this rule is an option, the caretakers applied it more than in the experiment. When the context allows elision or diphthongization, the caretakers showed the same rate of application for both rules, while in the Nogueira's experiment, elision was employed much more often. It was never the case that the adult applied a different process than expected.

10 One could ask if vowel degemination in BP could be analyzed as a type of elision, both of them being deleting rules. However, as we can see in Table 1, these rules have different properties. While vowel degemination may apply between any two identical vowels, elision is blocked if the first vowel is [-back]. Degemination is also blocked if the second syllable carries intonational prominence, while elision is blocked if the first syllable carries any kind of stress. Finally, another difference - not relevant to the present study - is that elision may only apply between words, while degemination (and diphthongization) may also apply word internally (see Bisol 1996).

11 See also Bisol (2002) for an overall picture of this distribution taking into consideration more dialects.

12 The first column indicates the kind of rule expected, based on the segments and prominences involved. The four following columns indicate what the output was. For more details concerning the materials, see section 5 below. 


\begin{tabular}{|l|l|l|l|l|l|}
\hline \multirow{2}{*}{ Target } & \multicolumn{2}{l|}{ Mothers' production } & \multirow{2}{l}{ Total } \\
\cline { 2 - 5 } & No application & Diphthongization & Elision & Degemination & \\
\hline Diphthongization & $47(24,7 \%)$ & $141(74,2 \%)$ & $2(1 \%)$ & $0(0 \%)$ & 190 \\
\hline Elision & $12(30 \%)$ & $0(0 \%)$ & $28(70 \%)$ & $0(0 \%)$ & 40 \\
\hline Vowel degemination & $5(4,9 \%)$ & $0(0 \%)$ & $0(0 \%)$ & $96(95 \%)$ & 101 \\
\hline Diphthongization or Elision & $9(7 \%)$ & $60(46,8 \%)$ & $59(46 \%)$ & $0(0 \%)$ & 128 \\
\hline
\end{tabular}

Table 2. Application of sandhi rules in mothers' utterances

\section{PREVIOUS STUDIES ON PHONOLOGICAL ACQUISITION IN BRAZILIAN PORTUGUESE}

Given that diphthongization involves complex syllable structures and that prosodic prominences are relevant for elision and degemination, one would in principle expect the acquisition of these sandhi rules to interact with the acquisition of syllable structure and prosodic prominences. Below I present a brief review of these different acquisition processes in BP, which will be relevant for the discussion of our results in section 7 .

\subsection{ACQUISITION OF SANDHI RULES IN BP}

Examining data from children from 2;0 to 3;0 years old, from Porto Alegre, Kickhöfel (2006) claims that children never overapply sandhi rules. According to her, children in fact resort to strategies to avoid sandhi: they either introduce pauses between words or delete the second vowel instead of the first one. The last strategy is taken to be employed to avoid diphthongization and to change the characteristics of elision. However, it is not clear from the analysis why children should avoid external sandhi rules to begin with, and more importantly, why children should change the characteristics of elision or use elision to avoid diphthongization. After all, incorrect deletion of a segment to avoid diphthongization amounts to overapplication of elision.

Most studies on the acquisition of BP in fact take the opposite stand, concurring to the idea that children overapply sandhi rules at some point of the phonological development. Scarpa (1997), for instance, proposes that the initial instability amounts to both over- and underapplication of sandhi rules. Crucially, she assumes that sandhi rules are used by adults to rhythmically optimize their utterances and proposes that children's cases of over-and underapplication are a by-product of their attempts to conform to such optimization. Following up on this study, Abaurre, Galves, and Scarpa (1999) point out that when the first two-word utterances appear (around 2;0), the application of degemination and elision is unstable. Interestingly, however, children never incorrectly apply these rules 
if one of the syllables in the context carries intonational prominence. The authors interpret this sensitivity to intonational prominences as evidence that children at this age already master higher prosodic domains, but are still acquiring a lower level of the prosodic hierarchy (the foot).

This initial instability receives a different analysis in Komatsu and Santos (2007). Although agreeing with Scarpa (1997) about the importance of intonational prominences in children's early outputs, they argue that the instability results not from under- or overapplication of the rules, but rather from the choice of the rules themselves. Examining data from one child from 1;6 to 3;6 years old, they identify three stages in the acquisition of external vowel sandhi. The first stage (from $1 ; 8$ to 2;6) starts when the child puts two words together and has the following characteristics: (a) the application of sandhi is unstable; (b) the sandhi rules applied are different from the ones used by adults (children usually use elision instead of diphthongization); (c) the rules are not used to optimize the rhythm of the utterances; and (d) phrasal stress blocks sandhi rules. In the second stage (around 3;0) we find the following: (a) sandhi rules are still unstable, sometimes use in a way different from adults'; and (b) the rules are used for rhythm optimization, unlike what happened in the previous stage. Finally, in the third stage (from 3;6 on) the application of the rules is adultlike: (a) the rules are stable; (b) there is no deletion of wrong segments anymore; and (c) the rules do not necessarily turn the outputs into optimal rhythmic sequences.

One problem common to Scarpa (1997), Abaurre, Galves, and Scarpa (1999), and Komatsu and Santos (2007) is the assumption that children are dealing with rhythmic optimization when they apply sandhi rules. In fact, it is not even clear that adults use the rules discussed here to attain more eurhythmic outputs. Adults may employ sandhi processes even when they produce stress clashes or lapses, and the same happens with children. Take, for instance, Scarpa's (1997) analysis of the utterance in (24), which is to be associated with the structure in (25). She proposes that the child overapplies elision in (24) (ignoring the stress on the second syllable, which should prevent the application of the rule) in order to optimize the rhythm of the utterance. This seems to tacitly assume that no sandhi rule is available for the structure in (25) in adult language. However, diphthongization is a possibility, as shown in (26) below. In other words, children's and adults' outputs differ not in terms of eurhythmy - the alternations in both the child's and adults' utterances are basically the same -, but in terms of the rule employed - elision instead of diphthongization.

(24) [vo.pu.'la.ta'vejs]

(25) [[Vou puLAR]ø [OUtra VEZ]ø]।

go-3sg-PRES jump other time 'I'm going to jump again.'

(26) [vo.pu.'law.tra.'vejs] 
Discussing the acquisition of the segmental and prosodic aspects of elision in BP, Santos (2009) analyzed V\#V sequences, both in contexts where elision could be applied in adult language (either for being the only possible rule or for being a context where elision or diphthongization could apply) and contexts where it couldn't. She found that children applied elision differently from adults, in a less restricted way. Specifically, Santos showed that children apply elision since the beginning of the acquisition process and that the contexts always satisfy the requirements for elision in adult language: the presence of one [+back] vowel and at most one strong syllable. However, children apply elision disregarding the position of the [+back] vowel, as shown in (27) and (28), or the position of the strong syllable, as shown in (29) and (30).

(27) [[ Olha look-3sg-PRES brother

(28) [ Esse $\alpha \mathrm{QUI}] \varnothing[$ menino ]ø ]। this here boy

(29) [[ seGUra Essa ]ø [aQUl ]ø ]। hold-IMP15 this here

(30) [[ ca $D \hat{E}] \varnothing[$ QQUEla PONte ]ø ]। where that bridge
['a:Ki'mãw]

$\mathrm{L} 1 ; 11$

'look the brother.'

['dej.zi.'ki.mi.'ni.nu]

'This here (is a) boy.'

[si.'gu.'le.sa.'ki]

'Hold this (one) here.'

[ka.'de.'ke.la.'põw.tri]

'Where is that bridge?'

These patterns led Santos to propose that the acquisition of the terms of the rule and the acquisition of their positional properties are independent and are not acquired simultaneously. That is, children may have already learned that the vowel should be [+back], but not that the [+back] vowel should be in first position. The same holds with respect to the strong syllable. A strong syllable is allowed in adult language, but it must be in the second position of the context. Children apply the rule with strong syllables, but do not restrict them to the second position.

Furthermore, since elision was never applied in a context without a [+back] vowel or between two strong syllables, Santos argues that this provides strong evidence against Newton and Wells's (2002) proposal. Under their proposal, children should apply elision in contexts involving vowels other than [+back], and with the following combination of prominences: weak-weak, weak-strong, strong-weak and strong-strong (which do not occur in adult language). Once children never overapply elision in these contexts, Santos points out, it cannot be the case that they are learning when not to apply it.

To sum up, the results discussed in this section reveal that in BP, sandhi rules are not acquired at once. The acquisition of their properties is spread throughout the course of language development, with prosodic properties being acquired before segmental ones. Given the appropriate contexts, sandhi rules apply as early as the first two-word 
combinations. The initial application of the rules is not adult-like, but overapplication is arguably not the result of rhythmic optimization. It should be pointed out that except for Santos (2009), none of the studies reviewed above discussed the acquisition of the properties of the rules themselves. Additionally, Komatsu and Santos (2007) and Kickhöfel (2006) showed a preference for elision instead diphthongization, but they do not explain why this should be so. Taking Santos's (2009) results on the acquisition of elision into account and extending her approach to other contexts and rules, in section 7, I will propose a unified analysis to account for the observed over- and underapplications of sandhi rules in BP, as well as the fact that children sometimes apply a rule different from adults'.

\subsection{ACQUISITION OF SYLLABLE STRUCTURE IN BP}

According to Collischonn (1997), in BP, syllables allow branching onsets (2 elements) and branching rimes (with at most 3 elements under the rhyme and glides filling the coda). Bisol (2013) argues that BP only has falling diphthongs, and that rising diphthongs are the result of a post-lexical diphthongization process. In GV sequences, $G$ fills the onset. Many studies point to the variable pronunciation of rising diphthongs in these contexts: diphthongs, hiatus and monophthongs (cf. CÂMARA JR. 1970; GONÇALVES and RODRIGUES 2012; HORA 2013, among others). As far as we know, there is no study on the distribution of patterns of rising diphthongs in the paulista dialect. As for the carioca dialect, Gonçalves and Rodrigues (2012) show that GV sequences are produced as rising diphthongs most of the times (the production of /ia and /oa/ as diphthongs reaches $100 \%$ ), followed by monophthongs (usually word-finally), and hiatus are very uncommon (/ea/ and /io/ appear in 1,3\% and $2,3 \%$ of the times, respectively). ${ }^{13}$

Studies on the acquisition of syllable structure in BP show that the structures with complex onsets are the last ones to be acquired (see SANTOS, 1998 and Mezzomo; Menezes 2001, among others), ${ }^{14}$ which is in consonance with what was found in other languages (e.g. Freitas, 1997 for European Portuguese; and Fikkert, 1994; and Levelt; Schiller; Levelt, 2001 for Dutch). According to Santos (1998) and Mezzomo and Menezes (2001), the general sequence of syllabic development in BP is as represented in (31) and the specific development revealed by the children analyzed here is presented in Table 3:
(31) $\mathrm{V}, \mathrm{CV}>>$
CVC, CVG
branching rhyme (nucleus \& coda)
$\gg$ CGV, CCV
branching onset

\footnotetext{
13 Cristófaro-Silva and Faria (2014), studying the mineiro dialect, observe that word-final syllables with sequences for rising diphthongs may also be produced with the complete deletion of the vowels, which leads to a ressylabification of the consonant of the onset to the previous syllable (10\% with a back vowel - as in árduo 'arduous' and $38 \%$ with a front vowel - as in série'series'. The mineiro dialect is known for presenting much more deletion than the other dialects in Brazil. As far as we know, no study showed this deletion in the paulista dialect.

14 In both studies, the structure is considered to be acquired when children reach $80 \%$ of correct production and does
} not go below this mark in the following sections. 


\begin{tabular}{|c|c|c|c|c|c|c|c|c|}
\hline & \multicolumn{2}{|l|}{ V } & \multirow{3}{*}{ CV } & CVC & \multicolumn{3}{|l|}{ CVV } & \multirow{3}{*}{$\mathrm{CCV}$} \\
\hline & \multirow[b]{2}{*}{ initial } & \multirow[b]{2}{*}{ medial } & & \multirow[b]{2}{*}{ final and medial } & \multicolumn{2}{|c|}{ falling diphthong ${ }^{15}$} & \multirow{2}{*}{$\begin{array}{l}\text { rising } \\
\text { diphthong }\end{array}$} & \\
\hline & & & & & heavy & light & & \\
\hline R. & $1 ; 5$ & $1 ; 11$ & $1 ; 5$ & $1 ; 11$ & $1 ; 6$ & $1 ; 5$ & $2 ; 0$ & $2 ; 0$ \\
\hline L. & $1 ; 4$ & $1 ; 7$ & $1 ; 4$ & $1 ; 8$ & $1 ; 5$ & $1 ; 9$ & $1 ; 9$ & $1 ; 9$ \\
\hline
\end{tabular}

Table 3. Acquisition of syllable structure by R. and L.

As can be seen in Table 3, onsetless syllables in word initial position appear at the same time as CV syllables. CVV syllables appear in two different moments: falling diphthongs (VG) appear around 1;6 - at the same time as CVC syllables -, while rising diphthongs (GV) appear later - at the same time as CCV. It is worth observing that the fact that CGV patterns with CCV and not with CVG provides further indication for the analysis of rising diphthongs in BP in terms of complex onsets (see section 2). If CGV filled a branching rhyme, it should appear at the same time as CVG, contrary to fact.

I will return to this development in section 7 .

\subsection{ACQUISITION OF PROSODIC PROMINENCES IN BP}

In BP the default prominence of the intonational phrase falls on the rightmost phonological phrase and word stress can fall on one of the three final syllables (the stress on the third syllable from the end is due to extrametricality). ${ }^{16}$ There are not many acquisition studies dealing with prosodic domains in BP, except for the acquisition of intonational prominence (SCARPA, 1997, 1999 and SANTOS, 1995, 2001) and word stress (SANTOS, 2001 and BONILHA, 2005).

Scarpa (1999) shows that most of children's first utterances - around 1;4 years old involve a template of four syllables with stress on the penultimate syllable: $(\sigma) \sigma^{\prime} \sigma(\sigma)$. It is worth mentioning that the position of the prominence remains the same regardless of whether or not the first and the last syllables are realized. According to her, children use filler-sounds in order to fill this template. Santos (1995) further shows that when children truncate their first words, they also comply with the template observed by Scarpa. ${ }^{17}$ Investigating the acquisition of the word stress algorithm by children from 1;2 to 3;6 years

15 The distinction between heavy and light diphthongs follows Bisol (1989), according to whom light diphthongs can be reduced, while heavy ones cannot. For example, ['pej. si] 'fish' can alternate with ['pe. si], but ['pej.tu] 'breast' cannot be produced as ['pe.tu].

16 See Bisol (1992), Massini-Cagliari (1995), and Lee (1995) for relevant discussion.

17 Although this reveals the dominance of the intonational domain in this period, Santos (1995) points out that the choice of the syllables to be deleted in the truncation process also takes into account syllable structure (onsetless syllables are more likely to undergo deletion). See Gerken (1994) and Wijnen, Krikhaar and Den Os (1994) for relevant discussion. 
old, Santos $(2001,2003)$ also argues that before children acquire word stress, they use intonational prominence as the prominence of their words. ${ }^{18}$

As for the acquisition of word stress proper, Santos $(2001,2003)$ shows that children first start manipulating many different intonational contours (from 1;3 to 2;0) and later choose one of these contours as a template to be matched (from 1;5 to 2;3). In these two stages, the prominence is always to the right, as is the prominence of the intonational domain. In a third stage (from 1;10 to 2;5), children assume that words are disyllabic and have the prominence either on the final or the penultimate syllable. Finally, in the last stage (from 2;3 on), children acquire extrametricality and also produce words with stress on the third syllable from the end.

\section{HYPOTHESES AND PREDICTIONS}

As seen in section 2, syllable structure and prosodic prominences are relevant for sandhi rules in BP. This then raises the question of whether the acquisition of sandhi rules interacts with the acquisition of syllable structure and prosodic prominences depicted in section 3. For example, in order to master the adult format of diphthongization, children should first learn that complex syllable structures are allowed in the language and that no syllable involved in a diphthongization can carry intonational prominence. In this paper I will explore the general conjecture that acquisition of sandhi rules interacts with acquisition of other phonological domains (specifically, syllable structure and prosodic hierarchy), examining the following specific hypotheses:

a) Given that children must learn that branching nucleus and branching onsets are necessary to produce diphthongs in $\mathrm{BP}$, the acquisition of diphthongization should be contingent on the acquisition of syllable structure;

b) Given that prominences from lower prosodic levels are acquired later than prominences from higher levels, children should initially disregard lower prominences, overapplying sandhi rules.

\footnotetext{
18 Scarpa's (1995) and Santos's $(1995,2001,2003)$ results are in consonance with crosslinguistic studies that show that early language is stable as far as sentence stress is concerned (see, among others, CRYSTAL, 1979; DORE, 1975; LOCKE, 1983; MENN, 1976; PETERS, 1977; SCHERER, 1981; VIGÁRIO; FROTA, 1992). This picture also accords well with Dore et al. (1975) and Vigário and Frota's (1992) proposals, according to which children initially use an inventory of intonational contours to interact with adults in different ways, despite their lack of developed segmental and lexical structures.
} 


\section{METHODOLOGY}

The corpus examined here is part of the 'Projeto de Aquisição da Linguagem' of the Universidade Estadual de Campinas (LEMOS, 1995) and the 'Projeto de Aquisição do Ritmo' of the Universidade de São Paulo (SANTOS, 2005)..$^{19}$ It consists of production data from two Brazilian children from the state of São Paulo - R. (from 1;3 to 3;6 years of age), and L. (from 1;4 to 3;6 years of age). Spontaneous production by the children was audiorecorded on a monthly basis, in half-hour sessions, in a naturalistic way. The data were phonetically transcribed on a perceptual basis and latter double-checked by researchers of one of the projects. Only the data whose transcriptions were agreed upon were taken into consideration here.

The children's utterances collected for this analysis were those containing more than one word, with the relevant context for the sandhi rules: the first word ending in an open syllable and the second word beginning with an onsetless syllable. The utterances were either in the same intonational phrase or in two intonational phrases produced sequentially by the children without interruption by the interviewer. ${ }^{20}$

In the 55 sessions analyzed, children produced 11.333 utterances. There were $3.020 \mathrm{V \# V}$ sequences and 1.931 contexts for external vowel sandhi. In order to analyze how children apply the sandhi rules discussed here, all the contexts were first classified according to the process that could occur in adult language: (i) diphthongization, (ii) elision, (iii) degemination, (iv) diphthongization or elision (when either rule could apply), and (v) no application (when no rule could apply). The contexts were then computed according to what the child produced.

19 This corpus does not require the approval from the Research Ethics Committee by complying with Resolution 510, of April 7, 2016, article 1, sole paragraph, V. According to this Resolution, data banks for research in Humanities do not need approval by an Ethics Committee if the identity of the participants in the records is kept confidential (http://www.conselho.saude.gov.br/resolucoes/2016/Reso510.pdf).

20 Given that in the age span analyzed, children are still in the process of acquiring determiners, I disregarded ambiguous data that could be analyzed as lacking the relevant determiner. For example, it is not possible to determine whether the form in (ia) results from applying elision to the underlying form in (ib) or whether the child is not using the determiner, as in (ic). Accordingly, unambiguous data such as (iia) were computed in the analysis of diphthongization, as their overt determiner (cf. (iib)) surfaces as a glide.
(i) a. [ $\varepsilon$. 'ar.vo. гi]
(it) is the tree.
b. / $\varepsilon$ a 'arvore/ is the tree
(ii) a. [Ew.a.vi. 'ãw]
'(It) is the airplane.
b. $/ \varepsilon \quad u \quad a v i$ ãw/
is the airplane
c. / $\varepsilon$ 'arvore/
is tree




\section{RESULTS}

Below I present the results on misapplication of sandhi rules found in the corpus and describe the stages that children seem to go through in the acquisition of these rules in BP.

\subsection{MISAPPLICATION OF SANDHI RULES}

In the corpus we find three different kinds of misapplication of sandhi rules: a) application of rules in wrong contexts (that is, contexts that would not allow any rule to apply); b) application of a wrong rule (that is, the context is for one rule in adult language, but children apply another rule in their utterances); c) and wrong application of the rules (that is, the context and the rule chosen are correct, but children apply the rule in a way different from adults').

\subsubsection{APPLICATION OF SANDHI RULES IN WRONG CONTEXTS}

Let's first see the cases where children applied a given rule in contexts where no rule should apply. We find examples of this type of overapplication with the three rules examined in this paper, as shown below.

\section{a) Elision}

Incorrect applications of elision in contexts where no rule should apply involved violations of segmental and prosodic requirements. The application with wrong segments is exemplified in (32), where the first vowel is [-back], which should prevent elision. As for violations of prosodic requirements, there were cases of incorrect application of elision between strong-weak syllables as shown in (33). It is worth mentioning that there was no case of incorrect application of elision involving a syllable carrying intonational prominence.

(31) [[e oniversário ]ø [ do PAto DQnald] ]ø ]। and birthday of-the duck Donald

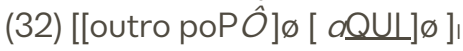
other pacifier here

$$
\begin{aligned}
& \text { [i.ni.ve.'ra.'pa.tu.'do.na] } \quad \text { L.2;921 } \\
& \text { 'and Donald Duck's birthday.' } \\
& \text { ['o.tu.po.'po.'ki] } \quad \text { R.1;9 } \\
& \text { 'another pacifier here.' }
\end{aligned}
$$

21 In her review of the present paper, Marina Vigário raises the question of whether words such as aniversário 'birthday' involve deletion of the onsetless first syllable. A preliminary examination of the data shows that for words with an onsetless syllable, R produced the onsetless syllable in $91,45 \%$ of the cases, deleted it in $7,6 \%$ of the cases, and inserted a consonant in $0,85 \%$ of the cases; and L produced the onsetless syllable $77,47 \%$ of the cases, deleted it in $16,21 \%$, and inserted a consonant in $6,3 \%$ of the cases. This indicates that children do not have problems in producing onsetless syllables. In Santos (in preparation) I will address Vigário's question taking into account the adjacent segments and prosodic boundaries of the target syllable. 


\section{b) Degemination}

The only restrictions on degemination are prosodic: it cannot apply between two stressed syllables or if the only stressed syllable carries the intonational prominence. Children applied degemination in both of these contexts, as shown in (33), with two strong syllables, and (34), with an intonational prominence:

(33) [neNÊ[Esse aQUI ]ø ]। baby this here

(34) [quem que [ÉEssa ]ø ]। who that is this-fem

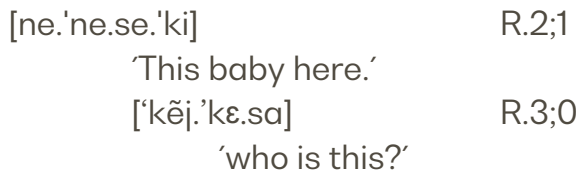

\section{c) Diphthongization}

The only cases of misapplication of diphthongization involved contexts with an intonational prominence and all of them involved wh-questions, as seen in (35).

(35) [que ÉE Esse]।

what is this [ne. ki.'kej.sI]

'what is this?'

\subsubsection{APPLICATION OF ONE SANDHI RULE FOR ANOTHER}

In the second type of misapplication, the context allows for the application of one rule but children apply another one. In the corpus, this case was restricted to instances where only diphthongization was allowed and children applied elision instead, as illustrated in (36), whose first vowel is [-back][+high], and (37), where the first vowel is strong:

(36) [aquele que foi [pra uniCAMp ]ø]। that one that went-3sg to Unicamp (37) [NÃO TOU enxuGANdo voÊE] not am drying you
['fo.pa.ni.'kã.pv]
The [nãw.'to.Ju.'gã.du] L.2;10 'l am not drying you.'

\subsubsection{APPLICATION DIFFERENT FROM ADULTS'}

Finally, children sometimes deleted the second vowel instead of the first one, when applying elision, as illustrated in (38). Importantly, one of the vowels was always [+back] and was the one that was maintained.

(38) [eu [QUEro]ø [anDAR]ø de BARco tamBÉM]। [e'ke.u.'da.dzi.'ba.ku.tã.'mẽi] L.2;11 I want-1sg-PRES walk of boat too 'I want to go on a boat ride, too' 


\subsection{STAGES IN THE ACQUISITION OF SANDHI RULES IN BP}

Based on misapplications of sandhi rules in BP, we can identify four stages in the acquisition process:

\section{a) Stage I}

At this point, children were not applying any rules. Tables 4 and 5 depicts R's and L's first stage. In R's data, there was only one context with two adjacent vowels in different words, but it was not an appropriate context for sandhi and R. correctly did not apply any rule. In $\mathrm{L}$ 's data, there were only $\mathrm{V} \# \mathrm{~V}$ contexts. Although four of them allowed diphthongization, $\mathrm{L}$ did not apply any rule.

\begin{tabular}{|l|l|l|l|l|l|}
\hline $1 ; 3-1 ; 7$ & R's production (1.031 utterances) & Diphthongization & Elision & Degemination & V\# contexts \\
\hline Target & No application & Dip & 0 & 0 \\
\hline Diphthongization & 0 & 0 & 0 & 0 & 0 \\
\hline Elision & 0 & 0 & 0 & 0 & 0 \\
\hline Degemination & 0 & 0 & 0 & 0 & 0 \\
\hline Dipht/Elision & 0 & 0 & 0 & 0 & $1(100 \%)$ \\
\hline${ }^{*}$ & $1(100 \%)$ & 0 & 0 & 0 & 1 \\
\hline Total & 1 & 0 & 0 & 0 & \\
\hline
\end{tabular}

Table 4. R's distribution of sandhi rules in the first stage.

\begin{tabular}{|l|l|l|l|l|l|}
\hline $1 ; 4-1 ; 6$ & L's production (1.031 utterances) & V\#V contexts \\
\hline Target & No application & Diphthongization & Elision & Degemination & V\# \\
\hline Diphthongization & $4(100 \%)$ & 0 & 0 & 0 & 0 \\
\hline Elision & 0 & 0 & 0 & 0 & 0 \\
\hline Degemination & 0 & 0 & 0 & 0 & 0 \\
\hline Dipht/Elision & 0 & 0 & 0 & 0 & 0 \\
\hline${ }^{*}$ & $2(100 \%)$ & 0 & 0 & 0 & $2(100 \%)$ \\
\hline Total & 1 & 0 & 0 & 0 & 6 \\
\hline
\end{tabular}

Table 5. L's distribution of sandhi rules in the first stage.

The utterances below exemplify what happens at this stage. The context in (39), for instance, allows diphthongization in adult language, whereas the context in (40) blocks the application of sandhi rules, due to the intonational prominence on the second vowel. In neither case did L. apply a sandhi rule.
(39) $\left[E_{\text {o caCÁ }}\right.$ ।
[ع.u.ka.'ka]
L.1;4
is the cacá (dog)
(40) $[0 \underline{\text { URso]। }}$
the bear
'It's the cacá.'
[a.'u.fi]
L.1;5
'the bear'

Since there were no instances of sandhi at this stage, it is not possible to determine if any properties of sandhi rules had been acquired. 


\section{b) Stage II}

At this stage sandhi rules start being applied. We can see in Tables 6 and 7 that both children applied degemination, elision, and diphthongization. As can be seen in Table 6, out of the 82 contexts of no application, $R$ applied a sandhi rule in 12 contexts (14.6\%) - 11 instances of elision and one instance of degemination. Table 6 also shows that in the contexts where only diphthongization was allowed, R applied elision in $22 \%$ of the time. Finally, when the context allowed diphthongization or elision, R preferred elision.

\begin{tabular}{|l|l|l|l|l|l|}
\hline $1 ; 8-2 ; 5$ & R's production (2.154 utterances) & Vlision & Degemination & V\#V contexts \\
\hline Target & No application & Diphthongization & Elion & $71(100 \%)$ \\
\hline Diphthongization & $32(45.7 \%)$ & $23(32.4 \%)$ & $16(22.5 \%)$ & 0 & $41(100 \%)$ \\
\hline Elision & $8(19.5 \%)$ & 0 & $33(80.5 \%)$ & 0 & $93(100 \%)$ \\
\hline Degemination & $8(8.6 \%)$ & 0 & 0 & $65(91.5 \%)$ & $90(100 \%)$ \\
\hline Dipht/Elision & $14(15.5 \%)$ & $11(12.2 \%)$ & $65(72.2 \%)$ & 0 & $82(100 \%)$ \\
\hline${ }^{*}$ & $70(85.3 \%)$ & 0 & $11(13.4 \%)$ & $1(1.2 \%)$ & 377 \\
\hline Total & 132 & 34 & 125 & 86 & \\
\hline
\end{tabular}

Table 6. R's distribution of sandhi rules in the second stage.

Although starting a bit earlier, L shows the same pattern, as can be seen in Table 7.19 of the $\mathrm{V} \# \mathrm{~V}$ sequences involved contexts of no application and $\mathrm{L}$ incorrectly applied elision or degemination in $47 \%$ of the cases. She never applied a different rule when elision or degemination was expected, but when the context was for diphthongization, she applied elision in $24 \%$ of the cases. When either diphthongization or elision could apply, L preferred elision. It is worth observing that $\mathrm{R}$ and $\mathrm{L}$ never applied diphthongization incorrectly at this stage.

\begin{tabular}{|l|l|l|l|l|l|}
\hline $1 ; 7-2 ; 3$ & L's production (1.360 utterances) & Degemination & V\#V contexts \\
\hline Target & No application & \multicolumn{1}{|l|}{ Diphthongization } & Elision & Degen & $45(100 \%)$ \\
\hline Diphthongization & $14(31.1 \%)$ & $20(44.4 \%)$ & $11(24.4 \%)$ & 0 & $10(100 \%)$ \\
\hline Elision & $4(40 \%)$ & 0 & $6(60 \%)$ & 0 & $32(100 \%)$ \\
\hline Degemination & $7(21.8 \%)$ & 0 & 0 & $25(781 \%)$ & $20(100 \%)$ \\
\hline Dipht/Elision & $4(20 \%)$ & $1(5 \%)$ & $15(75 \%)$ & 0 & $19(100 \%)$ \\
\hline${ }^{*}$ & $10(52.6 \%)$ & 0 & $6(31.5 \%)$ & $3(15.8 \%)$ & 126 \\
\hline Total & 39 & 21 & 38 & 28 & \\
\hline
\end{tabular}

Table 7. L's distribution of sandhi rules in the second stage.

The pairs in (41)-(43) illustrate lack of application and application of diphthongization, elision, and degemination, respectively. The $a$-cases involve an intonational prominence, which blocks sandhi, and children correctly complied with this restriction. In turn, the $b$-cases involve contexts with no intonational prominence - and children applied the relevant rule. 
(41) Diphthongization
a. [Acho que É]।
['a.su.ki.'e]
R.2;5
think-1sg-PRES that is
b. [que que Élsso],
[ki.'kie.'i.su]
'(l) think that (it) is.'
what that is this
'What is this?'

(42) Elision
a. [não QUEro
Esse] not want-1sg-PRES this
b. [COmo $\mathrm{He}$ CHAma]
how he name-3sg-PRES
[nãw.'ke.ru'esi]
'I don't wan't this.'
[ko'me.li.'Jã.ma]
R.1;9
'What's his name?'

(43) Degemination
a. [TInha Água]। had-3sg water
b. [[Tira $\alpha \mathrm{QUl}] \varnothing]$, take-IMP here
['ti.la.'a.ga]
R.1;11
'There was water.'
['ti.la'ki]
R.1;8

'Take this here.'

One could think that the application of the rules in the $a$-cases in (41)-(43) is prevented by prominences from lower levels and not by the intonational prominence. However, this is not the case. (41b) and (42b) illustrate the correct application of the rules in contexts that involve word prominences. Furthermore, (44) below presents a case where R applied degemination in a context with two strong syllables (none of them carrying intonational prominence) and this is not possible in adult language. This indicates that it is indeed the intonational prominence that is blocking the rules at this stage.
(44) $\left[[\right.$ neNÊ] $][\text { Esse aQUl ]ø }]_{1}$ baby this here

$$
\begin{aligned}
& \text { [ne. 'ne.se.'ki] } \\
& \text { 'This baby here.' }
\end{aligned}
$$

As for other prosodic restrictions on sandhi rules, children correctly applied the three sandhi rules in weak-weak contexts (cf. (45)-(47) below for diphthongization, degemination, and elision, respectively), degemination in a weak-strong context (cf. (42b)), and diphthongization in strong-weak contexts (cf. (48)). However, they incorrectly applied elision when the first syllable was stressed (cf. (49)): 
(45) [É Esse o CArro]।

is this the car

(46) [VIra oGQra]

turn-IMP now

(47) [[FEcha o ㅇlho]ø]। [maMÃE] $]$ । close-IMP the eye Mommy

(48) [[fora]ø [TÁ esCUro]ø ]। out is dark

(49) [es TOU amaSSANdo]

am kneading [ع.'e.sju.'ka.wo] L L.2;1

'(It')s this the car.'

['vi.'la.'go.la] R.1;9

'Turn (yourself) now.'

['fe.Ju.'o.kษ.mã.mãi] $\quad$ L.2;3

'Close your eyes, Mommy'

['fo.la.'tajs.'ku.la] L.2;0

'It is dark outside.'

['to.ma.'sã]

L. $2 ; 3$

'(I)'m kneading (it).'

As far as segmental properties are concerned, children never presented any problems with degemination. With respect to diphthongization, children behaved differently, depending on the position of the [+high] vowel. Cases where the [+high] vowel filled the second position, which would result in a falling diphthong (VG), always underwent diphthongization (cf. (50)); on the other hand, cases where the [+high] vowel was in first position, which would result in a rising diphthong (GV), usually underwent elision even if it was a [-back] vowel (cf. (51)). Crucially, falling diphthongs never underwent elision. Finally, children applied elision more regularly, but there were mistakes with respect to the segmental properties. Specifically, they also applied it when the second (and not the first) vowel was [+back] and this vowel was always the one that was deleted (cf. (52)):

(50) [[caDÊ obiCHInho]ø [daÍl ]ø]। where the puppy of-there

(51) [Abre dQU]] open here

(52) [[POde tirar ]ø [Esse $\propto \underline{\mathrm{QU}]}] \varnothing]$ can take-out this here

$$
\begin{aligned}
& \text { [ka.'dew.bi.'trĩ.da.'i] } \\
& \text { ['a.ba.'ki] } \\
& \text { Where is the puppy there? } \\
& \text { 'Open (it) here.' } \\
& \text { ['po.dzi.tfi.'la.se.'ki] }
\end{aligned}
$$

'(You) can take out this here.'

Table 8 summarizes the properties of sandhi rules in BP at this stage: 


\begin{tabular}{|c|c|c|c|c|c|}
\hline & \multirow[t]{2}{*}{ Process } & \multirow{2}{*}{$\begin{array}{l}\text { Segmental } \\
\text { properties }\end{array}$} & \multicolumn{2}{|c|}{ Prominences } & \multirow[t]{2}{*}{ Examples } \\
\hline & & & $1^{\text {st }}$ syllable & $2^{\text {nd }}$ syllable & \\
\hline $\begin{array}{l}\text { Vowel } \\
\text { degemination }\end{array}$ & not clear 22 & $\begin{array}{l}\text { Two identical } \\
\text { vowels }\end{array}$ & $\begin{array}{l}\text { W } \\
\text { W } \\
\text { S (*int) } \\
\text { S }\end{array}$ & $\begin{array}{l}\text { W } \\
\text { S (*int) } \\
\text { W } \\
\text { S }\end{array}$ & $\begin{array}{l}45 \\
42 a \\
\text { no evidence } \\
43\end{array}$ \\
\hline Elision & $\begin{array}{l}\text { deletion of the } \\
\text { [+back] vowel }\end{array}$ & $\begin{array}{l}\text { one of the vowels } \\
\text { must be [+back] }\end{array}$ & $\begin{array}{l}\text { W } \\
\text { W } \\
\text { S } \\
\text { S }\end{array}$ & $\begin{array}{l}\text { W } \\
S \text { ( }{ }^{*} \text { int.) } \\
W \\
S \text { ( }^{*} \text { int.) }\end{array}$ & $\begin{array}{l}46,50,51 \\
41 b \\
48 \\
\text { no evidence }\end{array}$ \\
\hline Diphthongization & $\begin{array}{l}\text { gliding of the } \\
\text { second vowel }\end{array}$ & $\begin{array}{l}\text { The second vowel } \\
\text { must be [+high] }\end{array}$ & $\begin{array}{l}\text { W } \\
\text { W } \\
\text { S } \\
\text { S }\end{array}$ & $\begin{array}{l}\text { W } \\
\text { S (*int.) } \\
\text { W } \\
\text { S (*int.) }\end{array}$ & $\begin{array}{l}44 \\
40 a \\
47,49 \\
\text { no evidence }\end{array}$ \\
\hline
\end{tabular}

Table 8. Summary of children's sandhi rules in the second stage.

\section{c) Stage III}

The third stage differs from the second one in that the application of elision decreases, making room for diphthongization to apply to cases where no rule was allowed. In this stage, $\mathrm{R}$ applied some rule in $7.8 \%$ in contexts of no application (cf. Table 9). The child also continued applying elision in contexts that only allowed diphthongization. In the cases where either diphthongization or elision could apply, R preferred elision.

\begin{tabular}{|l|l|l|l|l|l|}
\hline $2 ; 6-3 ; 4$ & \multicolumn{5}{|l|}{ R's production (2.703 utterances) } \\
\hline Target & No application & Diphthongization & Elision & Degemination & V\#V contexts \\
\hline Diphthongization & $94(31.7 \%)$ & $185(62.5 \%)$ & $17(5.7 \%)$ & 0 & $296(100 \%)$ \\
\hline Elision & $35(53.3 \%)$ & 0 & $64(64.6 \%)$ & 0 & $99(100 \%)$ \\
\hline Degemination & $18(10.9 \%)$ & 0 & 0 & $147(89.1 \%)$ & $165(100 \%)$ \\
\hline Dipht/Elision & $33(14.8 \%)$ & $62(27.8 \%)$ & $128(57.4 \%)$ & 0 & $223(100 \%)$ \\
\hline * & $366(92.2 \%)$ & $8(2 \%)$ & $21(5.3 \%)$ & $2(0.5 \%)$ & $397(100 \%)$ \\
\hline Total & 546 & 255 & 230 & 149 & 1180 \\
\hline
\end{tabular}

Table 9. R's distribution of sandhi rules in the third stage.

Table 10 presents the distribution of L's utterances in this period. In the 366 contexts of no application, she applied some rule in $11.3 \%$ the time. She continued applying elision in contexts where only diphthongization was allowed and preferred elision in contexts where there was a choice between diphthongization and elision. 


\begin{tabular}{|c|c|c|c|c|c|}
\hline $2 ; 4-3 ; 4$ & \multicolumn{5}{|c|}{ L's production (2.980 utterances) } \\
\hline Target & No application & Diphthongization & Elision & Degemination & V\#V contexts \\
\hline Diphthongization & $51(26.8 \%)$ & $78(41 \%)$ & $61(31 \%)$ & 0 & $190(100 \%)$ \\
\hline Elision & $11(23.4 \%)$ & $1(2.1 \%)$ & $35(74.4 \%)$ & 0 & $47(100 \%)$ \\
\hline Degemination & $11(10 \%)$ & 0 & 0 & $99(90 \%)$ & $110(100 \%)$ \\
\hline Dipht/Elision & $30(12 \%)$ & $46(18.4 \%)$ & $173(69.4 \%)$ & 0 & $249(100 \%)$ \\
\hline * & $324(88.5 \%)$ & $9(2.4 \%)$ & $31(8.4 \%)$ & $2(0.5 \%)$ & $366(100 \%)$ \\
\hline Total & 427 & 134 & 300 & 101 & 962 \\
\hline
\end{tabular}

Table 10. L's distribution of sandhi rules in the third stage.

At this stage, children correctly applied diphthongization between two strong syllables without intonational prominence (cf. (53)). Interestingly, they also began to incorrectly apply the rule when there was an intonational prominence involved - but only in wh-questions (cf. (54)). We may find correct applications of diphthongization in weakweak (cf. (55)), weak-strong (cf. (56)), and strong-weak (cf. (57)) contexts. In the contexts of weak-strong or strong-weak syllables, diphthongization never took place in contexts with an intonational prominence.

(53) [É Uma ROUpa $]_{1}$

is a cloth

(54) [que ÉEsse]

what is this

(55) [É o buRAco aSSIM],[olha]। is the hole like that look

(56) [qual que ÉDEssa], what that is of-this

(57) [o que TÁ esCRIto aQU]] the what is written here

$$
\text { [عw.ma.'ho.pa] L2;9 }
$$

'(That')s a cloth.'

$$
\text { [ki.'cj.si] }
$$

'What is this?'

[عw.bu.'ra.kwa.'si] $\quad$ L.2.3

'It is the hole like that, look.'

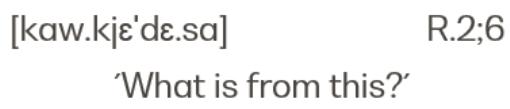

$$
\text { [u.ki'tajs.'ki.ta.'ki] L.2;3 }
$$

'What is written here?'

The same happens with degemination. The rule was applied correctly in contexts without an intonational prominence (cf. (58) for weak-weak contexts, (59) for strong-weak contexts, and (60) for weak-strong contexts), and incorrectly in contexts with an intonational prominence involving a wh-question (cf. (34), repeated here in (61)). Differently from the previous stage, two strong prominences together now block the rule (cf. (62)). 
(58) [É sujeiRI nha $a Q U I$ tamBÉM]। is dirt-dim. here too

(59) [o que que TÁ aconteCENdo]। the what that is happening

(60) [É o PElxe [na Água]ø]। is the fish in-the water

(61) [quem que [É Essa]ø ]। who that is this-fem

(62) [mas a da FLOR É Essa aQU] but the of-the flower is this here [su.ze.'ri.na.'ki.ta.'mẽi] L.2;7

'(It')s a small dirty here too.'

[ki.'ta.ku.te.'sẽ.du] L.2;8

'What is happening?'

['E'pej[ina'agwa] L.2;8

'(It')s the fish in the water.'

[kẽj.'kع.sa]

R.3;0

'Who is this?'

As for elision, children correctly applied it in contexts of weak-weak (cf. (63) below), or weak-strong (cf. (64)) syllables and still incorrectly applied it in contexts with a primary stress in the first vowel (cf. 65)). However, contrary to the case of degemination and diphthongization, they never applied elision if there was an intonational prominence in the context.

(63) [não QUE ro aBRIR]ı [não]। not want open not

(64) [Essa Émais GRANde]। this is more big

(65) [a GENte É irMÃ]! the people is sister

$$
\begin{gathered}
\text { ['ke.ra.'bri.nãw] L.2;5 } \\
\text { '(I) don't want to open, not.' }
\end{gathered}
$$

[sa.'majs.'gã.dzi]

'This one is bigger.'

[a. 'zẽ.'t][i.'mã] R.3;0

'We are sisters.'

As for the segmental properties of the rules, although there were still cases of application of elision instead of diphthongization, children produced diphthongs in contexts of GV more frequently (cf. (66)-(67)). Cases where no rule was allowed underwent diphthongization (cf. (53)) or elision (cf. (68)).

(66) [qual que ÉDEssa] what that is of-this

(67) [É o buRA co osSIM]! [이ha]। is the hole like that look

(68) [caDE $a \mathrm{QUEla}$ PONte]। where that bridge

$$
\begin{aligned}
& \text { [kaw.'kje.'de.sa] R.2;6 } \\
& \text { 'What is from this one?' } \\
& \text { ['Ew.bu.'ra.kwa.'sĩ] L.2;7 } \\
& \text { 'It is the hole like that, look.' } \\
& \text { [ka.'de.'ke.la.'põw.tfi] R.2;10 } \\
& \text { 'Where('s) that bridge?' }
\end{aligned}
$$

In summary, at this stage the properties of the rules are as follows: 


\begin{tabular}{|c|c|c|c|c|c|}
\hline & \multirow[t]{2}{*}{ Process } & \multirow{2}{*}{$\begin{array}{l}\text { Segmental } \\
\text { properties }\end{array}$} & \multicolumn{2}{|c|}{ Prominences } & \multirow[t]{2}{*}{ Examples } \\
\hline & & & $1^{\text {st }}$ syllable & $2^{\text {nd }}$ syllable & \\
\hline $\begin{array}{l}\text { Vowel } \\
\text { degeminatio } \\
n\end{array}$ & not clear & $\begin{array}{l}\text { Two } \\
\text { identical } \\
\text { vowels }\end{array}$ & $\begin{array}{l}\text { W } \\
W \\
S \text { (*int) } \\
{ }^{*} S\end{array}$ & $\begin{array}{l}\text { W } \\
\text { S } \\
\text { W } \\
\text { S }\end{array}$ & $\begin{array}{l}60 \\
57,58,61 \\
59 \text { (no evidence for the blocking } \\
\text { of intonation) } \\
62\end{array}$ \\
\hline Elision & $\begin{array}{l}\text { deletion of } \\
\text { the [+back] } \\
\text { vowel }\end{array}$ & $\begin{array}{l}\text { one of the } \\
\text { vowels must } \\
\text { be [+back] }\end{array}$ & $\begin{array}{l}\text { W } \\
W \\
S\end{array}$ & $\begin{array}{l}\text { W } \\
\mathrm{S}\left(^{*} \text { inton) }\right. \\
\text { W }\end{array}$ & $\begin{array}{l}63 \\
64 \\
65\end{array}$ \\
\hline $\begin{array}{l}\text { Diphthongiz } \\
\text { ation }\end{array}$ & $\begin{array}{l}\text { gliding of } \\
\text { the [+high] } \\
\text { vowel }\end{array}$ & $\begin{array}{l}\text { one of the } \\
\text { vowels must } \\
\text { be [+high] }\end{array}$ & $\begin{array}{l}\text { W } \\
\text { W } \\
\text { S (*int) } \\
\text { S }\end{array}$ & $\begin{array}{l}\text { W } \\
\text { S (*int) } \\
\text { W } \\
\text { S }\end{array}$ & $\begin{array}{l}54 \\
55 \\
56 \\
53,54\end{array}$ \\
\hline
\end{tabular}

Table 11. Summary of children's sandhi rules in BP in the third stage.

\section{d) Stage IV:}

The fourth stage is when children stopped overapplying the rules - cf. Tables 12 and 13. Table 12 shows R's distribution of the data. She correctly observed contexts for no application in $96.5 \%$ of the time. There was only one case of misapplication of elision instead of diphthongization. Finally, she continued preferring elision over diphthongization where both rules were allowed.

\begin{tabular}{|l|l|l|l|l|l|}
\hline $3 ; 5 \ldots$ & \multicolumn{4}{l}{ R's production (460 utterances) } \\
\hline Target & No application & Diphthongization & Elision & Degemination & V\#V contexts \\
\hline Diphthongization & $16(43.2 \%)$ & $20(54 \%)$ & $1(2.7 \%)$ & 0 & $37(100 \%)$ \\
\hline Elision & $3(33 \%)$ & 0 & $6(66 \%)$ & 0 & $9(100 \%)$ \\
\hline Degemination & $2(16.6 \%)$ & 0 & 0 & $10(83 \%)$ & $12(100 \%)$ \\
\hline Dipht/Elision & $1(6.2 \%)$ & $2(12.5 \%)$ & $13(81.2 \%)$ & 0 & $16(100 \%)$ \\
\hline${ }^{*}$ & $56(96.5 \%)$ & 0 & $2(3.4 \%)$ & 0 & $58(100 \%)$ \\
\hline Total & 78 & 22 & 22 & 10 & 132 \\
\hline
\end{tabular}

Table 12. R's distribution of sandhi rules in the fourth stage.

Table 13 presents L's data. There were 74 contexts of no application, which she observed in $97.3 \%$ of the cases. She overapplied elision instead of diphthongization just once. In cases where both rules were allowed, she preferred elision.

\begin{tabular}{|c|c|c|c|c|c|}
\hline $3 ; 5$ & \multicolumn{5}{|c|}{ L's production (413 utterances) } \\
\hline Target & No application & Diphthongization & Elision & Degemination & V\#V contexts \\
\hline Diphthongization & $4(21 \%)$ & $14(66.6 \%)$ & $1(5.2 \%)$ & 0 & $19(100 \%)$ \\
\hline Elision & $4(80 \%)$ & 0 & $1(20 \%)$ & 0 & $5(100 \%)$ \\
\hline Degemination & $2(8.7 \%)$ & 0 & 0 & $21(91.3 \%)$ & $23(100 \%)$ \\
\hline Dipht/Elision & $8(11.7 \%)$ & $2(11.7 \%)$ & $13(76.4 \%)$ & 0 & $17(100 \%)$ \\
\hline * & $72(97.3 \%)$ & 0 & $1(1.3 \%)$ & $1(1.3 \%)$ & $74(100 \%)$ \\
\hline Total & 84 & 16 & 16 & 22 & 138 \\
\hline
\end{tabular}

Table 13. L's distribution of sandhi rules in the fourth stage. 
The main differences between adults' and children's rules regarding prominences at stage IV have to do with children's applying elision in strong-weak contexts, and diphthongization and degemination in contexts involving an intonational prominence. (69) illustrates a case that fulfills the segmental requirements for elision, but not the prosodic ones (the first vowel carries primary stress). Correctly, children did not apply the rule. (70) and (71) show that wh-questions with an intonational prominence in the context stopped undergoing diphthongization and degemination. Finally, (72) and (73) below form a minimal pair, showing that diphthongization only applies when there is no intonational prominence involved. In (72) and (73) there is a context with two strong syllables, one of them with a [+high] vowel; however, in (72) the second syllable also carries intonational prominence, which prevents the application of the rule. Children correctly applied diphthongization in (73), but not in (72):23

(69) [que $T A ́$ esCRIto aQUl]। what is written here

(70) [quem é Esse]। who is this

(71) [quem é Essa]ı who is this

(72) [não POde la VAR Esse]। not can wash this '(You) cannot wash this (foot).' [ki.'ta.is.'ki.twa.'ki] L.3;6

'What's written here?'

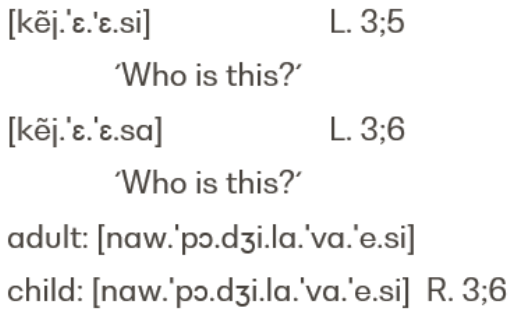

23 The context in (71) and (72) involves an infinitival verb and a determiner. In BP, infinitivals have an $\{-r\}$ morpheme, which is usually deleted in colloquial speech (for a quantitative analysis of this process, see Callou, Moraes and Leite (2002) and Cardoso (1999), among others). In case it is deleted, sandhi rules apply as described in section 2 (cf. (i)-(iii)), which suggests that the underlying (deleted) morpheme does not block these rules.

(i) Degemination:

(ii) Elision:

(iii) Diphthongization

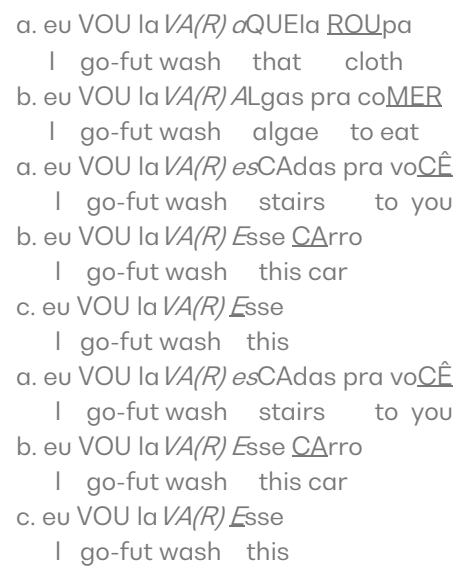

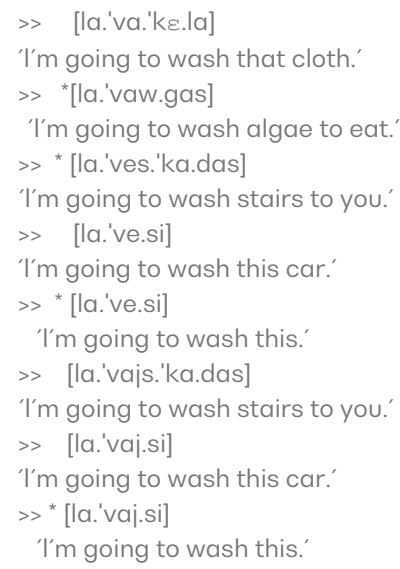


(73) [não POde la VAR Esse PÉ]। not can wash this foot

'(You) cannot wash this foot.' adult: [naw.'po.dzi.la.'vaj.si.'pe] [naw.'po.dzi.la.'ve.si.'pe]

child: [naw. 'po.dzi.la.'vaj.si.'pe]

R.3;6

To summarize, in this stage children reach the adult pattern described in Table 1.

\subsection{SUMMARY OF THE DEVELOPMENT OF THE THREE RULES}

Table 14 summarizes the properties of the three sandhi rules in the four stages:

\begin{tabular}{|c|c|c|c|c|}
\hline \multirow{3}{*}{ Properties } & \multicolumn{4}{|c|}{ Stages } \\
\hline & I & II & III & IV \\
\hline & \multicolumn{4}{|c|}{ Elision } \\
\hline Prominences & - & $\begin{array}{l}\text { W W } \\
\text { W S (only word stress) } \\
\text { S (only word stress) W }\end{array}$ & $\begin{array}{l}\text { W W } \\
\text { WS (only word stress) } \\
\text { S (only word stress) W }\end{array}$ & $\begin{array}{l}\text { W W } \\
\text { W S (only word stress) }\end{array}$ \\
\hline Segments & - & $\begin{array}{ll}\mathrm{V}_{\text {[+back] }} & \mathrm{V}_{\mathrm{V}} \\
\mathrm{V}_{\text {[+back] }} \\
\end{array}$ & $\begin{array}{ll}\mathrm{V}_{\text {[back] }} & \mathrm{V}_{\mathrm{V}} \\
\mathrm{V} & \mathrm{V}_{\text {[back] }} \\
\end{array}$ & $\mathrm{V}_{[+ \text {back }]} \mathrm{V}$ \\
\hline Process & - & deletion of the $\mathrm{V}_{[\text {[back }]}$ & deletion of the $V_{[\text {[back }]}$ & deletion of the first $V$ \\
\hline \multicolumn{5}{|c|}{ Degemination } \\
\hline Prominences & - & $\begin{array}{l}\text { W W } \\
\text { W S (*int) } \\
\text { no evidence for S("int)W }\end{array}$ & $\begin{array}{l}\text { WW } \\
\text { W S } \\
\text { S S } \\
\text { no evidence for S(*int)W }\end{array}$ & $\begin{array}{l}\text { W W } \\
\text { W S(*int) } \\
{ }^{*} S \mathrm{~S} \\
\text { no evidence for } S\left({ }^{*} \text { int)W }\right.\end{array}$ \\
\hline Segments & - & two identical vowels & two identical vowels & two identical vowels \\
\hline Process & - & not clear & not clear & not clear \\
\hline \multicolumn{5}{|c|}{ Diphthongization } \\
\hline prominences & - & $\begin{array}{l}\text { W W } \\
\text { W S (*int) } \\
\text { S (*int) W } \\
\text { S (*int) S (*int) }\end{array}$ & $\begin{array}{l}\text { W W } \\
\text { W S (*int) } \\
\text { S("int) W } \\
\text { no evidence for S S }\end{array}$ & $\begin{array}{l}\text { W W } \\
\text { WS(*int) } \\
\text { S (*int) W } \\
\text { S (*int) S (*int) }\end{array}$ \\
\hline segments & - & V gl & $\begin{array}{l}V \mathrm{gl} \\
\mathrm{glV}\end{array}$ & $\begin{array}{l}\vee g l \\
g l ~ V\end{array}$ \\
\hline process & - & gliding & Gliding & gliding \\
\hline
\end{tabular}

Table 14. Stages of acquisition of sandhi rules in BP.

\section{DISCUSSION}

As seen in section 6, there is a pattern of development in the acquisition of sandhi rules in BP. In the early stages children's production generally shows fewer prosodic and segmental restrictions than what is found in adult grammar. For instance, they incorrectly apply elision regardless of the position of the stressed syllable and they may do so even between two strong syllables. In addition, a [+ back] vowel suffices for elision to apply, regardless of its 
position in the context. This already shows that Bernhardt and Stemberger's (1998) speculation mentioned in section 1 that elision processes occur without errors in child language is not supported by the facts regarding BP.

Below I discuss whether the hypotheses raised in section 4 account for the results reported in section 6 .

\subsection{THE RELATION BETWEEN SANDHI RULES AND SYLLABLE STRUCTURE}

At first sight, the picture outlined in section 6 shows that diphthongization is at odds with the general pattern of elision and degemination in that it applies in fewer contexts than in adult grammar. In the second stage, diphthongization occurs when the [+high] vowel is in the second position, but not when the [+high] vowel fills the first position, in which case elision applies. This unexpected pattern can however find an explanation if my hypothesis that the acquisition of diphthongization is related to the acquisition of syllable structure (see section 4) is on the right track.

As shown in section 3, the syllable structures with complex onsets are the last ones to be acquired in BP (cf. Table 3). The pattern found by Santos (1998) and Mezzomo and Menezes (2001) is: V, CV > CVC, CVG > CGV, CCV. If there is a relation between the acquisition of diphthongization and the acquisition of syllable structure, then we should expect that falling diphthongs (which result from $\mathrm{V}+\mathrm{V}_{\text {[+high] }}$ sequences) should appear before rising ones (which result from $V_{[+h i g h]}+V$ sequences). More specifically, given that the branching rhyme parameter is set before the branching onset parameter (see FIKKERT, 1994; and FREITAS, 1997; among others), we should find a stage when falling diphthongs should be produced correctly, while contexts that would result in rising diphthongs should not trigger diphthongization.

This is exactly what was found in the data. In the case of rising diphthongs, children applied elision (which requires a CV structure) over diphthongization (which requires a branching onset) at 1;11, but very infrequently after 2;0. Therefore, it is arguably the case that children chose one rule over another not because of the rules themselves, or because they are using it as a strategy to avoid diphthongization (as claimed by Kickhöfel, 2006), but rather because they have not yet acquired the syllable structure required to apply diphthongization. In an initial period, when only the branching nucleus parameter is set, children produce falling diphthongs, but fail to produce rising diphthongs. When the 
branching onset parameter is set (allowing both CCV and CGV sequences), children start applying diphthongization to their outputs and do not apply the "wrong" rule anymore. ${ }^{24}$

It is important to observe that children's choice of elision instead of diphthongization is not a reflex of the input. As seen in section 2.5, their mothers applied diphthongization in $74 \%$ of the cases, elision in $70 \%$ of the cases, and there was a very uniform distribution of the rules when either elision or diphthongization could take place: $46,8 \%$ application of diphthongization and $46 \%$ application of elision. Most importantly, they incorrectly applied elision in diphthongization contexts only in $1 \%$ of the time ( 2 instances). Furthermore, children overapplied elision only in contexts of rising diphthongs and this again does not reflect the input.

One could think that incorrect applications of elision instead of diphthongization were guided by the Elsewhere Condition (Kiparsky, 1973), in the sense that children would choose the rule with more restrictions first. If we compare elision and diphthongization, the former has more restrictions than the latter (cf. Table 1). In order for elision to apply, the target of deletion (a [+back] vowel) must be in the first position; the context can only involve weakweak or weak-strong syllables; and a strong syllable can carry word stress, but not prominences from higher levels. As for diphthongization, a [+high] vowel has no restrictions on its position; there are no restrictions on the combination of weak and strong syllables; and the strong syllable can carry prominences up to the phonological phrase level. However, if the Elsewhere Condition were the key factor, we would be unable to explain why the contexts for falling diphthongs did not trigger elision, as opposed to contexts for rising diphthongs. After all, diphthongization has the same number of restrictions regardless of whether the output is a falling or a rising diphthong.

\subsection{EFFECTS OF PROSODIC PROMINENCES}

Early sensitiveness to prosody has been emphasized in various studies on language acquisition. As early as 7,5 months old, infants are sensitive to prosodic prominences and units (see Gerken; Jusczyk; Mandel, 1994; Jusczyk; Houston; Newsome, 1999; and Davis et al. 2000). As far as the acquisition of the phonological inventory is concerned, Vihman (1996) argues that phonological organization begins when children have about 50-word

24 In her review, Marina Vigário asks whether the different moments of acquisition for rising and falling diphthongs could be due to a possible alternation in GV sequences being produced as diphthongs or hiatuses. As we pointed out in Section 3.2, in both the carioca and the mineiro dialects, the production of diphthongs prevails in these contexts and variation is only found in word-final contexts. Although we do not have studies on the distribution of different productions of GV sequences in the paulista dialect, it does not seem to be likely that variation in only one context (weak word-final syllables) should suffice to play a role in the acquisition of these sequences. Freitas et al (2006), for instance, discussed the acquisition of different syllable types in European Portuguese and concluded that frequency of syllable types in adult language did not play a role in the acquisition process. 
cumulative vocabulary and already display some prosodic templates (syllables and words). Other studies further show that the acquisition of segmental properties is contingent on prosodic domains (see Hernandorena, 1990; Marshal; Chiat, 2003; and Morrisette; Dinnsen; Gierut, 2003). Finally, Mattys et al. (1999) show that when phonotactics and prosody contradict each other, 9-month-olds rely on prosody to segment words.

As for the acquisition of the prosodic domains themselves, there is no consensus. One view is that all the prosodic domains are available since the beginning of the acquisition process (see DEMUTH, 1996; KEHOE, 2001; among others), another view is that lower levels are acquired before higher ones (see DEMUTH, 1995; DEMUTH; FEE, 1996), and finally, that (in the case of BP) the intonational domain is acquired prior to the acquisition of lower domains (SCARPA, 1997; SANTOS, 2001, 2003; JORDÃO; FROTA, 2010; FROTA ET AL, 2016). Despite their differences, all these studies concur that the acquisition of the prosodic properties takes place early and that the segmental inventory is organized taking prosodic units into consideration.

Given this overall picture, I raised the hypothesis in section 4 that when acquiring sandhi rules in BP, children pay close attention to prosodic units and should overapply sandhi rules while the relevant prosodic requirements have not been acquired yet. More specifically, since intonational prominence is acquired very early, this prominence should never be disregarded in the application of the rules, whereas prominences that are acquired later could be. If correct, this hypothesis should shed more light on the debate regarding the order of the acquisition of prosodic domains. Let us then see how this hypothesis fares given the results presented in section 6.

As seen in section 1, in adult language external vowel sandhi rules cannot apply when there is an intonational prominence in the context. In addition, degemination cannot apply if the context has two strong syllables, regardless of the kind of prominence involved (word stress, phonological phrase prominence, or intonational prominence). If children did not apply degemination in a strong-strong context that does not involve an intonational prominence, we would not be able to determine whether they are not applying the rule because it is optional or whether they are taking into account lower levels in the prosodic hierarchy. On the other hand, if children applied degemination in this context, this would show that they are not taking the prominences from lower levels into consideration, but only the one from the intonational level.

As we saw in section 6, in the second stage children applied degemination between two strong syllables, as exemplified in (44), repeated here in (74).

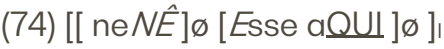
[ne.'ne.se.'ki]
baby this here
'This baby here.' 
In (74), the two syllables of the context /ne.e/ carry word stress in adult language (the first one carries phonological phrase stress, as well). If children took these prominences into account, they should not apply degemination, contrary to fact. Thus, (74) shows that at this stage the prominences from lower levels do not prevent the application of the rule.

Let us finally examine the exceptional misapplications of sandhi rules seen in stage III. The first thing that calls our attention is that there is an asymmetry: while we find incorrect applications of degemination and diphthongization in contexts with an intonational prominence, as respectively illustrated in (75) and (76) below, this never happens with elision. The second point worth noticing is that the exceptional cases all involve (complete or incomplete) formulaic wh-questions of the type 'what is this?'.

(75) [quem que [É Essa ]ø ]। who that is this-fem

(76) [que ÉE Esse], what is this-masc [kẽj.'ke.sa] 'Who is this?'

[ki.'ci.si]

'What that is this?
R.3;0

In adult language, questions of this type create the following phonological contexts (with

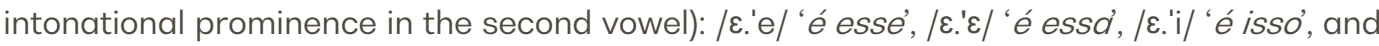
/e.' $\varepsilon /$ 'que $\hat{e}$. Putting aside the intonational prominence, the segmental properties of these contexts allow for diphthongization and degemination only, not elision. Once children disregard intonational prominences only in these $w h$-questions, they never show incorrect applications of elision in these contexts. Thus, it is not the case that intonational prominences became occasionally irrelevant at this stage.

There remains the question of why children applied diphthongization and degemination only in these contexts. As seen above, it is not any kind of wh-questions that undergoes overapplication, but only questions like 'o que é (isso)?' 'what is this?'. ${ }^{25}$ This kind of question appears very early in children's production and is not restricted to BP. Brown (1973) observes that the same kind of question ('what is that?') appears early in children acquiring English. His proposal is that this kind of sentences has a fixed frame and is not the product of grammar. This accords well with other analyses that propose that in the early stages children show some formulaic sequences in their outputs (see Jespersen, 1924/1976; Peters, 1977, 1983; Plunket, 1993; and WRAY, 2002; among others). Formulaic sentences are defined as strings of several words in adult language that are treated and stored as single units by children. They characteristically display grammatical properties that will only show up later on in the acquisition process (PETERS, 1977), are less precise in articulation (PLUNKET, 1993), and are refractory to stress change (JESPERSEN, 1924/1976). Peters (1983) further

25 In fact, the questions subject to diphthongization and degemination are all variations of 'o que é isso?': 'o que é essa?' (demonstrative-feminine), 'o que é esse?' (demonstrative-masculine), 'quem que é essa?' 'who is that? 
proposes that formulaic sentences can be reanalyzed by children in a later stage when they take note of their internal prosodic properties (rhythm, stress, and intonation). Marina Vigário observes in her review that the processes are occurring with high frequent combinations of items from closed classes, which could suggest that the sequence was undergoing a reduction process (along the lines discussed in VIGÁRIO, 2003). In BP adult language, both degemination and diphthongization can occur even between two strong syllables (SS), provided that none carry intonational prominence. Therefore, such reduction should be understood as a reduction of the intonational prominence.

In the paulista dialect, adults may exceptionally apply diphthongization to $w h$-questions even when the strong syllable carries intonational prominence, as illustrated in (77), which involves a weak and a strong syllable:

(77) [que que É] what that is [ki.'kje] 'what is (it)?

This fits well with Vigário's (2003) proposal. However, in SS contexts that involve intonational prominence, adults apply neither diphthongization nor degemination, which indicates that the reduction does not apply in these contexts, despite its high frequency in adult language:

(78) degemination: Quem que é essa?

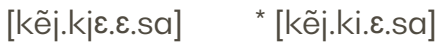

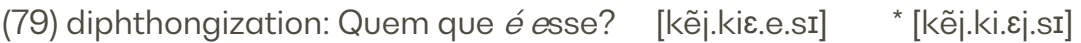

Therefore, although the frequency of the items must certainly play a role, it cannot be the only reason for children's misapplication of the rules. Otherwise, the processes under discussion would also occur in adult language, contrary to fact.

My proposal is that the sentence 'o que é (isso)?' is a formulaic sentence in the data examined during stages II and III. This sentence appears earlier than other wh-questions in childrens' outputs. Children arguably select this structure from a larger input sentence, ${ }^{26}$ which includes another word to the right carrying the intonational prominence, as in (77), for example, and use it as a frozen expression (as in (78)).

(80) [quem que ÉÉssa aQUI] $>$ adults: [kẽj.'kj'.sa.'ki] who that is this here 'Who is this here?

(81) quem-que-é-essa? (no internal analysis) $\quad>\quad$ children: [kẽj.'kiं.sa] 'Who's this?' 
At stage IV, children stop overapplying diphthongization and degemination in these contexts. At this stage, they are 3;5 years old and other wh-structures have been acquired. Following Peters's (1983) proposal, it is very plausible to conclude that children are now generating the structures associated with 'o que é (isso)?' and thus the production of these sentences with diphthongization and degemination no longer occurs.

This proposal is corroborated by the order of appearance of different wh-sentences corroborates. Analyzing three children from the paulista dialect (one of them being R, one of the children studied here), Grolla (2000) shows that while sentences like 'o que é isso?' appear when children are 2;2 years old, other interrogatives that have the same structure only appear at 2;9 years old. ${ }^{27}$

To conclude, the developmental pattern displayed by children acquiring BP provides evidence against Newton and Wells's (2002) proposal that what children must learn is when not to apply juncture rules. If elision applied automatically and did not need to be learned, as the authors propose, children acquiring BP should employ elision disregarding segmental and prosodic requirements in the early stages. However, this is not the case. As seen above, aside from formulaic sentences, children never violate the intonational prominence restriction on elision (and degemination), which shows that sandhi rules in BP do not apply automatically and must be learned.

\subsection{SUMMARY}

I have proposed that children acquire the properties of sandhi rules (including the order of the contexts) independently and that sandhi rules are dependent on the acquisition of syllable structure and prosodic prominences. This proposal explains the findings on the overapplication of sandhi rules and the application of sandhi rules in a way different from adults'. As seen in section 3 above, studies on the acquisition of sandhi rules have documented overapplication in contexts of no application (Scarpa, 1997; Abaurre; Galves; Scarpa, 1999; and KOMATSU; SANTOS, 2007), the application of one rule for another (KOMATSU; SANTOS, 2004; Kickhöfel, 2006), and the application of rules deleting segments in wrong positions (see KOMATSU; SANTOS, 2007; Kickhöfel, 2006). Here I showed that overapplication occurs because (a) children do not acquire all the properties of the rules at the same time and (b) children do not apply some sandhi rules at some stages simply because they have not acquired the proper syllable structure yet. 


\section{CONCLUDING REMARKS}

In this paper I discussed the acquisition of external vowel sandhi rules in BP. The importance of studying the acquisition of rules that exist in the target language is that we can observe the changes children make in their outputs in order to acquire the adult grammar. Specifically for sandhi rules, it has been argued that (some of) these rules are adult-like since the beginning and would not need to be learned. By analyzing when and how the rules are applied by children when compared to adults, I showed that these rules are not acquired at once, but become more adult-like as the language development proceeds. I showed that the first properties acquired by children in the acquisition of sandhi rules are the prosodic ones: the intonational and word stress prominences, in this order. That is, since the beginning children never apply sandhi rules over intonational prominences, although they may apply the rules in wrong contexts, where other prominences (word prominences) or segments different from the ones in adult rules are involved. These results corroborate Santos's (2009) work on the acquisition of elision, in which she argues that only in a later moment do children acquire the properties regarding the features of the vowels involved in the contexts for application of sandhi and that the order of the terms of the elision rule in BP is acquired independently. This is actually the last property of the rules that is acquired.

We also saw that the choice of the rules to be applied depends on other parts of the phonological development. More specifically, children used elision instead of diphthongization before they acquired the syllabic structure that would allow them to diphthongize.

The analysis developed here has the advantage of providing a unified explanation for two facts noted in previous studies: the overapplication of (some) sandhi rules in early stages and the application of these rules in a way different from adults'. Children overapply sandhi rules and apply them differently because they do not acquire all the terms of the rules simultaneously and because the application of sandhi rules is dependent on the acquisition of syllable structure.

\section{ACKNOWLEDGEMENTS}

An early version of this research was presented in Santos (2007). I would like to thank CNPq for its support to this research (grant \#303533/2019-6). I would also like to thank Paula Fikkert, Carmen Matzenaver, Jairo Nunes, and Marina Vigário, for their comments and suggestions. 


\section{REFERENCES}

ABAURRE, M. B. M., C. Galves; SCARPA, E. A interface fonologia-sintaxe. Evidências do português brasileiro para uma hipótese top-down na aquisição da linguagem. In: SCARPA, E. Estudos de Prosódia. Campinas: Ed. da Unicamp, 1999, p. 285-323.

BERNHARDT, B. H.; STEMBERGER, J. P. Handbook of phonological development - from the perspective of constraint-based nonlinear phonology. California: Academic Press, 1998.

BISOL, L. O ditongo da perspectiva da fonologia atual. D.E.L.T.A., São Paulo, vol. 5, n. 2, p. 185-224, 1989.

BISOL, L. Sândi vocálico externo: degeminação e elisão. Cadernos de Estudos Lingüísticos, Campinas, n. 23, p. 83-101, 1992

BISOL, L. Sândi externo: o processo e a variação. In: KATO, M. Gramática do Português Falado, v. 5. Campinas: UNICAMP, 1996, p. 55-96.

BISOL, L. A sílaba e seus constituintes. In: NEVES, M. H. Gramática do Português Falado, V. 7 Campinas: UNICAMP, 1999, p. 701-742.

BISOL, L. A degeminação e a elisão no VARSUL. In: BISOL, L.; BRESCANCINI, C. Fonologia e Variação Recortes do Português Brasileiro. Porto Alegre: EDIPUCRS, 2002, p.231-250.

BISOL, L. Sandhi in Brazilian Portuguese. Probus v. 15, n. 2, p. 177-200, 2003.

BISOL, L. A sílaba e seus constituintes. In: ABAURRE, M.B.M. Gramática do português culto falado no Brasil: A construção fonológica da palavra v. 7, p. 21-52, 2013.

BONILHA, G. F. G. Aquisição Fonológica do Português Brasileiro: uma abordagem conexionista da teoria da otimidade. 2005 Thesis (PhD in Linguistics) Pontifícia Universidade Católica do Rio Grande do Sul, Porto Alegre, 2005.

BROWN, R. A First Language. Cambridge, Mass: Harvard University Press, 1973.

CALLOU, D.; MORAES, J. A.; LEITE, Y. Variação e diferenciação dialetal: a pronúncia do /R/ no português do Brasil. KOCH, I.G. Gramática do Português Falado v. VI: Desenvolvimentos. Campinas, Editora da Unicamp, 2002, p. 463-490.

CÂMARA JR, J. M. Estrutura da língua portuguesa. Petrópolis: Vozes: 1970.

CARDOSO, W. (1999) A quantitative analysis of word-final/r/-deletion in Brazilian Portuguese. Linguistica Atlantica n. 21, p. 13-52, 1999.

CASALI, R. F. Vowel elision in hiatus contexts: which vowel goes? Language vol.73, n. 3, p. 493-528, 1997.

COLLISCHONN, G. Análise prosódica da Sílaba em Português. Thesis (PhD in Linguistics) Pontifícia Universidade Católica do Rio Grande do Sul, Porto Alegre, 1997.

CRISTÓFARO-SILVA, T.; FREITAS, I. Percursos de ditongos crescentes no português brasileiro. Letras de Hoje v. 29, n. 1, p. 19-27, 2014.

CRYSTAL, D. "Prosodic Development" In: FLETCHER, P; GARMAN, M. Language Acquisition. Cambridge University Press, 1979, p. 33-48.

DAVIS, B. L.; MACNEILAGE, P. F.; MATYEAR, C. L.; POWERLL, J. K. Prosodic Correlates of Stress in Babbling: an acoustical study. Child Development n. 71, p. 1258-1270, 2000.

DEMUTH, K. Issues in the acquisition of the Sesotho tonal system. Journal of Child Language n. 20, p. 275-301, 1993.

DEMUTH, K. Markedness and the development of prosodic structure. In: BECKMAN, J. Proceedings of the North East Linguistic Society Amherst, MA: GLSA, 1995, v. 25, p. 13-25. 
DEMUTH, K. The prosodic structure of early words. MORGAN, J.; DEMUTH, K. Signal to Syntax: Bootstrapping from Speech to Grammar in Early Acquisition Hillsdale: Lawrence Erlbaum Associates. 1996, p. 171-184.

DEMUTH, K; FEE, E. J. Minimal prosodic words in early phonological development, ms, Brown University \& Dalhousie University, 1996

DORE, J. Holophrases, speech acts and language universals. Journal of Child Language n. 2, p. 21-40, 1975.

DORE, J; FRANKLIN, M. B.; MILLER, R. T.; RAMER, A. L. H. Transitional phenomena in early language acquisition. Journal of Child Language n. 3, p. 13-28, 1975.

DRACHMAN, G. Generative phonology and child language acquisition. Ohio State University Working Papers in Linguistics n. 15, p. 146-159, 1973.

DRESHER, B. E.; KAYE, J. D. A computational learning model for metrical phonology. Cognition n. 34, p. 137-195, 1990.

FIKKERT, P. On the Acquisition of Prosodic Structure. Holland: Holland Institute of Generative Linguistics, 1994.

FREITAS, M. J. Aquisição da estrutura silábica no Português Europeu. 1997 Thesis (PhD in Linguistics), Universidade de Lisboa, Lisbon, 1997.

FREITAS, M. J.; FROTA, S.; VIGÁRIO, M.; MARTINS, F. Efeitos prosódicos e efeitos de frequência no desenvolvimento silábico do português europeu. In: OLIVEIRA, F; BARBOSA, J. Textos Seleccionados - XXI Encontro Nacional Da Associação Portuguesa De Linguística, N. 21. Lisboa: Associação Portuguesa de Linguística. p.397-412, 2006.

FROTA, S; CRUZ, M; MATOS, N.; VIGÁRIO, M. Early prosodic development: emerging intonation and phrasing in European Portuguese. In: HENRIKSEN, N; ARMSTRONG, M.E; VANRELL, M. M. Interdisciplinary approaches to intonational grammar in Ibero-Romance. Philadelphia, USA: John Benjamins, p. 295-324, 2016.

GERKEN, L. A. A metrical Template account of children's weak syllable omissions from multisyllabic words Journal of Child Language, vol. 21, p. 565-584, 1994.

GERKEN, L. A.; JUSCZYK, P.; MANDEL, D. R. When prosody fails to cue syntactic structure: nine-month-olds' sensitivity to phonological vs. syntactic phrases. Cognition n. 51, p. 237-265, 1994.

GONCCALVES, C. A. V.; RODRIGUES, M. C. Encontros vocálicos finais átonos na fala carioca: abordagem por ranking de restrições. Letras \& Letras (UFU, impresso), v. 28, p. 186-208, 2012.

GROLLA, E. B. A Aquisição da Periferia Esquerda da Sentença em Português Brasileiro. Dissertation (Master in Linguistics) Universidade Estadual de Campinas, Campinas. 2000.

HERNANDORENA, C. Aquisição da Fonologia do Português: estabelecimento de padrões com base em traços distintivos. 1990 Thesis (PhD in Linguistics), Pontifícia Universidade Católica do Rio Grande do Sul, Porto Alegre. 1990

HORA, Dermeval da. Monotongação de ditongos crescentes: realidade linguística e social. In: LOBO, Tânia (Org.). Rosae. Salvador: EDUFBA, 2013. v. 1. p. 349-357.

JESPERSEN, O. Learning grammar. Reprinted in: BORNSTEIN, D. Readings in the Theory of Grammar. Cambridge: Winthrop Publishers, 1924/1976, p. 82-93.

JORDÃO, R; FROTA, M. The intonational phrase constrains coda development. In: CASTRO, A; COSTA, J; LOBO, M; PRATAS, F. Language Acquisition and Development - Proceedings of GALA 2009. Cambridge: Cambridge Scholars, p. 240-251. 2010

JUSCZYK, P.; HOUSTON, D., NEWSOME, M. The beginnings of word segmentation in English-learning infants. Cognitive Psychologyn. 39, p. 159-207, 1999.

KEHOE, M. Prosodic Patterns in Children's multisyllabic word productions. Language, Speech and Hearing Services in Schools vol. 32, p. 284-294, 2001. 
KIKHÖFEL, J. O processo de sândi externo na aquisição da fonologia do português brasileiro - uma abordagem com base na teoria da otimidade. 2006 Dissertation (Master in Linguistics). Universidade Católica de Pelotas, Pelotas, 2006.

KIPARSKY, P. Elsewhere' in phonology. In: ANDERSON, S; KIPARSKY, P. A Festschrift for Morris Halle New York: Holt, Rinehart \& Winston, 1973, p. 93-106.

KLEIN, H. B. Learning to stress: a case study. Journal of Child Language n. 2, p. 375-390, 1984.

KOMATSU, M.; SANTOS, R. S. A variação na aquisição s regras de sândi externo em Português Brasileiro. D.E.L.T.A. n 23 (2), p. 223-244, 2007.

LEE, S. Morfologia e Fonologia Lexical do Português Brasileiro. 1995. Thesis (PhD in Linguitics), Universidade Estadual de Campinas, Campinas. 1995 UNICAMP.

LEMOS, C. T. G. Aquisição da Linguagem. Report to FAPESP 1976/1384 FAPESP 1985/3325-6 CNPq $404672-$ 88.4 FAEP 190/90, ms. Universidade Estadual de Campinas, 1995.

LEVELT, C.; SCHILLER, N.; LEVELT, W. The acquisition of syllable Types. Language Acquisition 1999/2000 vol.8. I. 3, p. 237-265, 2001

LOPES, B. S. The sound pattern of Brazilian Portuguese: Cariocan dialect. 1979. Thesis (PhD in Linguistics) University of California Los Angeles. Los Angeles, 1979

MARSHAL, C.; CHIAT, S. A foot domain account of prosodically-conditioned substitutions. Clinical Linguistics and Phonetics v. 17, n. 8, p. 645-657, 2003.

MASSINI-CAGLIARI, G. Cantigas de Amigo: do Ritmo Poético ao Linguístico. Um Estudo do Percurso Histórico da Acentuação em Português. Thesis (PhD in Linguistics) Universidade Estadual de Campinas, Campinas. 1995.

MATEUS, M. H. M.; D’ANDRADE, E. The Phonology of Portuguese Oxford University Press, 2000.

MATTYS, S.; JUSCZYK, P.; LUCE, P.; MORGAN, J. Phonotactic and prosodic effects on word segmentation in infants. Cognitive Psychologyn. 38, p. 465-494, 1999.

MENN, L. Pattern, control and contrast in beginning speech: a case study in the development of word form and word function. Thesis (PhD in Linguistics) University of Illinois, 1976.

MEZZOMO, C.; MENEZES, G. Comparação entre a aquisição da estrutura silábica no português brasileiro e no português europeu Letras de Hoje vol. 36 n. 125, p. 691-698, 2001.

MORRISSETTE, M.; DINNSEN, D.; GIERUT, J. Markedness and Context Effects in the Acquisition of Place Features. Canadian Journal of Linguistics n.48 (3/4), p. 329-355, 2003.

NESPOR, M.; VOGEL, I Prosodic Phonology Dordrecht: Foris Publications, 1986

NEWTON, C.; WELLS, B. The development of between-word rules in the connected speech of children aged between three and seven In: MAASSEN, B.; GROENEN, P. Pathologies of speech and language. Advances in Clinical Phonetics and Linguistics. London: Whurr, 1999, p. 275-299.

NEWTON, C.; WELLS, B. Between-word junctures in early multi-word speech. Journal of Child Language vol. 29, p. 275-299, 2002.

NOGUEIRA, M. V. Aspectos Segmentais dos Processos de Sândi Vocálico Externo no Falar de São Paulo. Dissertation (Master in Linguistics). Universidade de São Paulo, São Paulo, 2007.

OLIVEIRA, A. S. C. L. Aquisição de Constituintes QU- em dois Dialetos do Português Brasileiro. Dissertation (Master in Linguistics). Universidade Estadual de Campinas, Campinas, 2003.

PETERS, A. Language learning strategies: does the whole equal the sum of the parts? Language n. 53, p. 560$573,1977$. 
PETERS, A. The Units of Language Acquisition - monographs in applied psycholinguistics. Cambridge: Cambridge University Press, 1983.

PLUNKET, K. (1993) "Lexical segmentation and vocabulary growth in early language acquisition. Journal of Child Language n. 20, p. 43-60, 1993.

SANTOS, R. S. Uma interface fonologia-sintaxe: o uso de sons preenchedores da categoria funcional dos determinantes. 1995 Dissertation (Master in Linguistics). Universidade Estadual de Campinas, Campinas, 1995.

SANTOS, R. S. A aquisição da estrutura silábica. Letras de Hoje n. 112, p. 91-98, 1998.

SANTOS, R. S. A aquisição do acento de palavra no Português Brasileiro. 2001 Thesis (PhD in Linguistics). Universidade Estadual de Campinas, Campinas, 2001.

SANTOS, R. S. Bootstrapping in the acquisition of word stress in Brazilian Portuguese. Journal of Portuguese Linguistics n. 2.1, p. 93-114, 2003.

SANTOS, R. S. Projeto de Aquisição do Ritmo em Português Brasileiro. Report to FAPESP \# 03/13565-4, 2005.

SANTOS, R. S. A aquisição prosódica do português brasileiro de 1 a 3 anos: padrões de palavra e processos de sândi externo. Livre Docência Thesis. Universidade de São Paulo, São Paulo, 2007.

SANTOS, R. S.. Segmental and Prosodic Aspects in the Acquisition of Elision in Brazilian Portuguese. In: CHANDLEE, J.; FRANCHINI, M.; LORD, S.; RHEINER, G. Proceedings of the 33rd annual Boston University Conference on Language Development. Somerville, MA: Cascadilla Press, 2009. v. 2. p. 456-467.

SCARPA, E. M. Learning external sandhi. Evidence for a top-down hypothesis of prosodic acquisition. In: SORACE, A.; HEYCOCK C.; SHILLCOCK, R. Shillcock, Proceedings of GALA'1997 Conference on Language Acquisition: knowledge representation and ruling. 1997, p. 272-277.

SCARPA, E. M. Sons preenchedores e guardadores de lugar: relações entre fatos sintáticos e prosódicos na aquisição da linguagem. In: SCARPA, E. M. Estudos de prosódia SP: Editora da Unicamp, 1999, p. 253-284.

SCHERER, K. R. Speech and emotional states. In: DARBY, J.J.K. Speech evaluation in Psychiatry. New York: Grune \& Stratton, 1981, p. 189-220.

STEMBERGER, J. P. Speech errors in early child language production. Journal of Memory and Language vol. 28 n.2, p. 164-188, 1989.

TENANI, L. E. Domínios prosódicos no Português do Brasil: implicações para a prosódia e para a aplicação de regras fonológicas. 2002 Thesis (PhD in Linguistics) Universidade Estadual de Campinas, Campinas, 2002.

VIGÁRIO, M. The Prosodic word in European Portuguese Interface Explorations Series, 6. Berlin/New York: Mouton de Gruyter, 2003.

VIGÁRIO, M; FROTA, S. Aquisição da Prosódia l: uma categorização das produções sonoras de e para a criança. Análise Psicológica, 4 (X), p. 457-478, 1992.

VIHMAN, M. M. Phonological Development - The origins of language in the child Cambridge, Mass: Blackwell Publishers, 1996

WIJNEN, F.; KRIKHAAR, E.; DEN OS, E. (1994). The (non)realization of unstressed elements in children's utterances: evidence for a rhythmic constraint. Journal of Child Language n. 29, p. 59-83, 1994.

WRAY, A. Formulaic Language and the Lexicon Cambridge: Cambridge University Press, 2002. 